\title{
Pre-seismic strain anomalies and coseismic deformation of Meinong earthquake from continuous GPS
}

\author{
Min-Chien Tsai ${ }^{1, *}$, Tzay-Chyn Shin $^{2}$, and Kai-Wen Kuo ${ }^{1}$ \\ ${ }^{1}$ Seismological Center, Central Weather Bureau, Taipei City, Taiwan \\ ${ }^{2}$ Central Weather Bureau, Taipei City, Taiwan
}

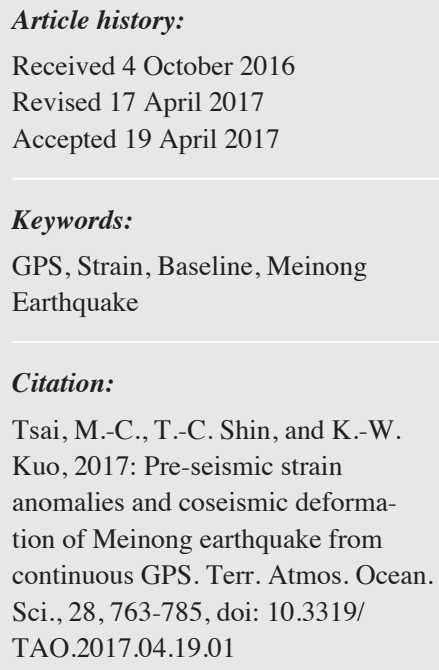

\begin{abstract}
High strain accumulation across the fold-and-thrust belt in SW Taiwan are revealed by the Continuous GPS (cGPS) from 2007 - 2015. This high strain is generally accommodated by the major active structures in fold-and-thrust belt of western Foothills. In addition, the plastic deformation of mudstone in the Gutingkeng formation might play a crucial role for aseismic creeping. Furthermore, the distributed rightlateral shear zone, fault-related folding and aseismic creeping are also dominated from Lungchuan fault and Chishan fault to the north of Kaohsiung area. Based on distribution of coseismic uplift across the Lungchuan fault to the Tainan tableland, a clear evidence of multiple fault slips was triggered by the $2016 \mathrm{M}_{\mathrm{w}} 6.4$ Meinong earthquake at $\sim 15 \mathrm{~km}$. The surface coseismic deformation is mainly controlled by a fault-related folding structures connected to the shallow décollement around $5-10 \mathrm{~km}$ depth, in which the moderate earthquakes locate in mid-crust could trigger slip along the weak décollement. The pre-seismic baseline variation of cGPS is observed in 8 baselines near the epicenter of the Meinong earthquake. The rate-slow-down anomalies of these baseline variation could be considered as a possible precursor of the Meinong earthquake.
\end{abstract}

\section{INTRODUCTION}

The modern technique of Global Positioning System (GPS) provides an efficient tool to study active tectonics and geodynamics (e.g., Dixon 1991; Hager et al. 1991; Bock 1994; Hudnut 1995; Segall and Davis 1997; Bürgmann and Thatcher 2013; Bock and Melgar 2016). The data from dense continuous GPS array provide us to estimate fault-slip rates, infer fault geometry, and assess regional seismic hazard (e.g., Bock et al. 1997; Sagiya et al. 2000; Lin et al. 2010). Taiwan is situated at an active collision boundary, in which numerous folds and thrust belts formed due to the convergence between the Luzon arc and the Chinese continental margin. Orogeny of Taiwan exhibits all the stages of the collision process from south to north: subduction along the Manila trench, incipient collision in south of Taiwan, active collision in southcentral Taiwan, and past collision in the northern part (Fig. 1; Teng 1990; Huang et al. 1997; Lallemand and Tsien 1997). As a result of these processes, the island shows a high rate of crustal deforma-

\footnotetext{
* Corresponding author

E-mail:minchyen@scman.cwb.gov.tw
}

tion and strong seismic activity (Shin 1992; Hsu et al. 2003; Wu et al. 2008a, b; Lin et al. 2010; Shin et al. 2011). The convergence rate across the Taiwan mountain belt is about $82 \mathrm{~mm} \mathrm{yr}^{-1}$ based on GPS measurements (Fig. 1; Yu et al. 1997, 1999; Hickman et al. 2002; Lin et al. 2010; Tsai et al. 2015). Numerous devastating earthquakes with magnitudes greater than 6 have occurred since 1900 in southern Taiwan (Fig. 2). Based on the analysis of the strain rate from GPS, several authors highlighted the southward escape of tectonic block along the major strike-slip fault in SW Taiwan (Bos et al. 2003; Chang et al. 2003; Ching et al. 2007; Lin et al. 2010). According to the crustal stain field in southwestern area base on the interseismic velocity field from 2004 - 2012 derived from GPS time series analysis (Tsai 2013), the shortening rate of $-1.4 \sim-1.55 \mu$ strain $\mathrm{yr}^{-1}$ and the maximum shear strain rate of about $0.8-0.9 \mu$ strain $\mathrm{yr}^{-1}$ are detected along a NE-SW trending fold-and-thrust belt. The high strain rate in SW Taiwan suggests that it is crucial to assess the seismic hazards in terms of strain accumulation in the study area.

The disastrous $\mathrm{M}_{\mathrm{w}}$ 6.4 Meinong Earthquake occurred 
on 6 February 2016 at Kaohsiung area of the SW Taiwan. This event caused lots of damages, injuries and 117 casualties in Tainan area. According to the earthquake location from the Central Weather Bureau (CWB), the epicenter of the Meinong earthquake located at $22.92^{\circ} \mathrm{N}$ and $120.54^{\circ} \mathrm{E}$ with the focal depth of $14.6 \mathrm{~km}$. The WNW-ESE striking left-lateral strike-slip fault with thrust component dipping to north (Fig. 1) was considered as the fault plane of this event according to the moment-tensor solution derived from inversion of broadband seismic waveforms data of Central Weather Bureau Seismic Network (CWBSN_BB). No surface fault system is associated with the rupture of the Meinong earthquake, thus this event is considered as a blind fault in SW Taiwan. In this study, we try to characterize the pre-seismic baseline variation and anomalous strain accumulation in SW Taiwan before the Meinong Earthquake based on continuous GPS (cGPS) data from 2007 - 2015. In addition, we also calculate the coseismic displacement filed with available cGPS data to characterize the deformation pattern induced by the Meinong event in terms of seismic activity, geological structures and seismic hazards.

\section{TECTONIC SETTING, BACKGROUND SEISMICITY, AND ACTIVE STRUCTURES IN SW TAIWAN}

The Taiwan mountain belt is formed by the oblique collision between the Philippine Sea Plate and the Eurasia Plate (Fig. 1). Northeast of the island, the Philippine Sea plate subducts northwestward underneath the Eurasian plate along the Ryukyu Trench. In the southern part of the tectonic domain, the South China Sea plate subducts beneath the Philippine plate along the Manila trench (Angelier 1986). The historical disastrous earthquakes mainly occurred along the Taiwan orogenic belt due to the on-going collision between Philippine Sea plate and Eurasian plate (Fig. 2). Among these devastating earthquake events, the disastrous Meishan earthquake in 1906 and Hsinhua earthquake in 1946 caused the surface ruptures, huge damages and deaths. There are more than 36000 earthquakes annually occurred

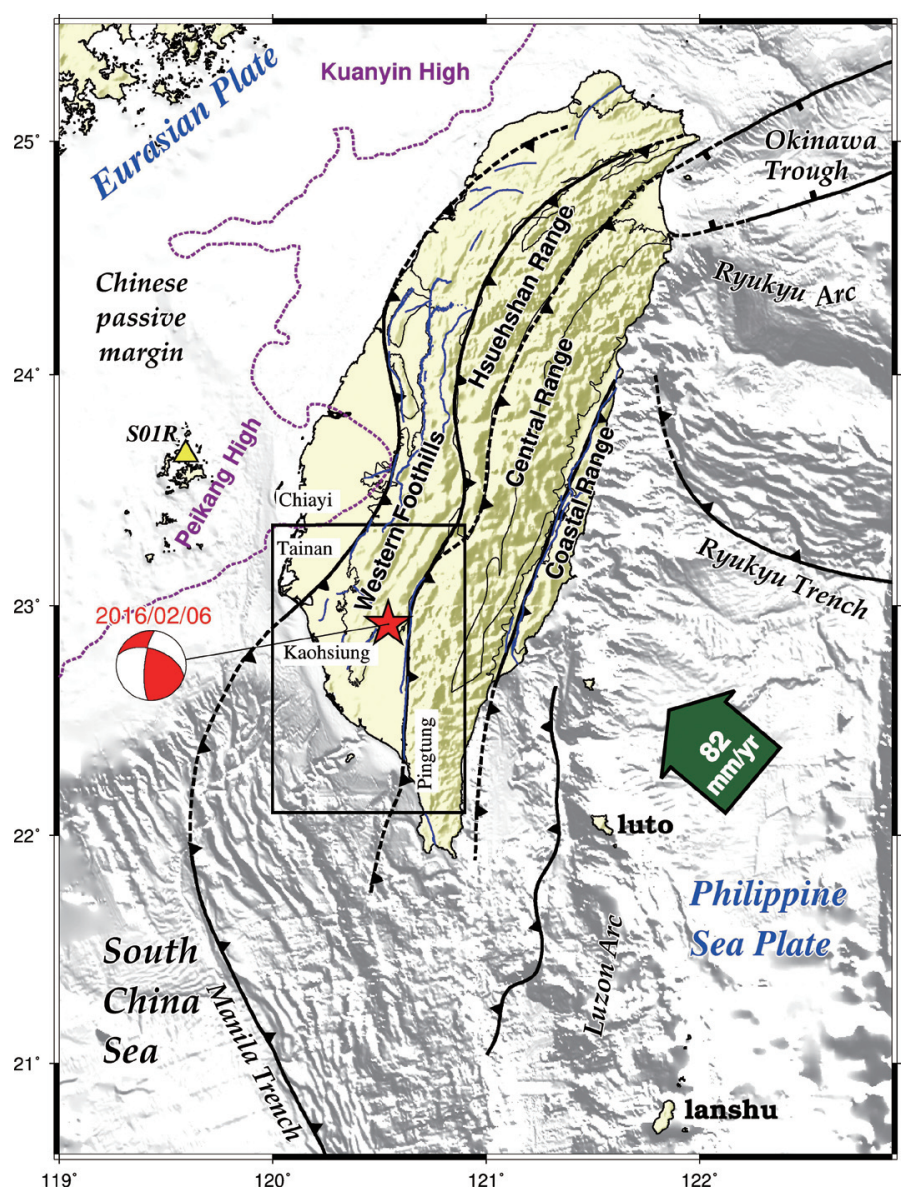

Fig. 1. Tectonic framework and major structures of Taiwan between the Eurasian and Philippine Sea plates. Large green arrow shows the convergence rate of $\sim 82 \mathrm{~mm} \mathrm{yr}^{-1}$ (Tsai et al. 2015, Table 2, Lanshu station, LANY). Purple dash line delineates the boundary of two basement highs (Lin and Watts 2002). Yellow triangle represents the cGPS stations at Penghu Paisha (S01R) located at relatively stable Eurasian plate. Blue solid lines demonstrate 33 active faults published by Lin et al. (2012). Red star indicates the epicenter of the Meinong earthquake with focal mechanism. Black rectangle denotes the study area. (Color online only) 


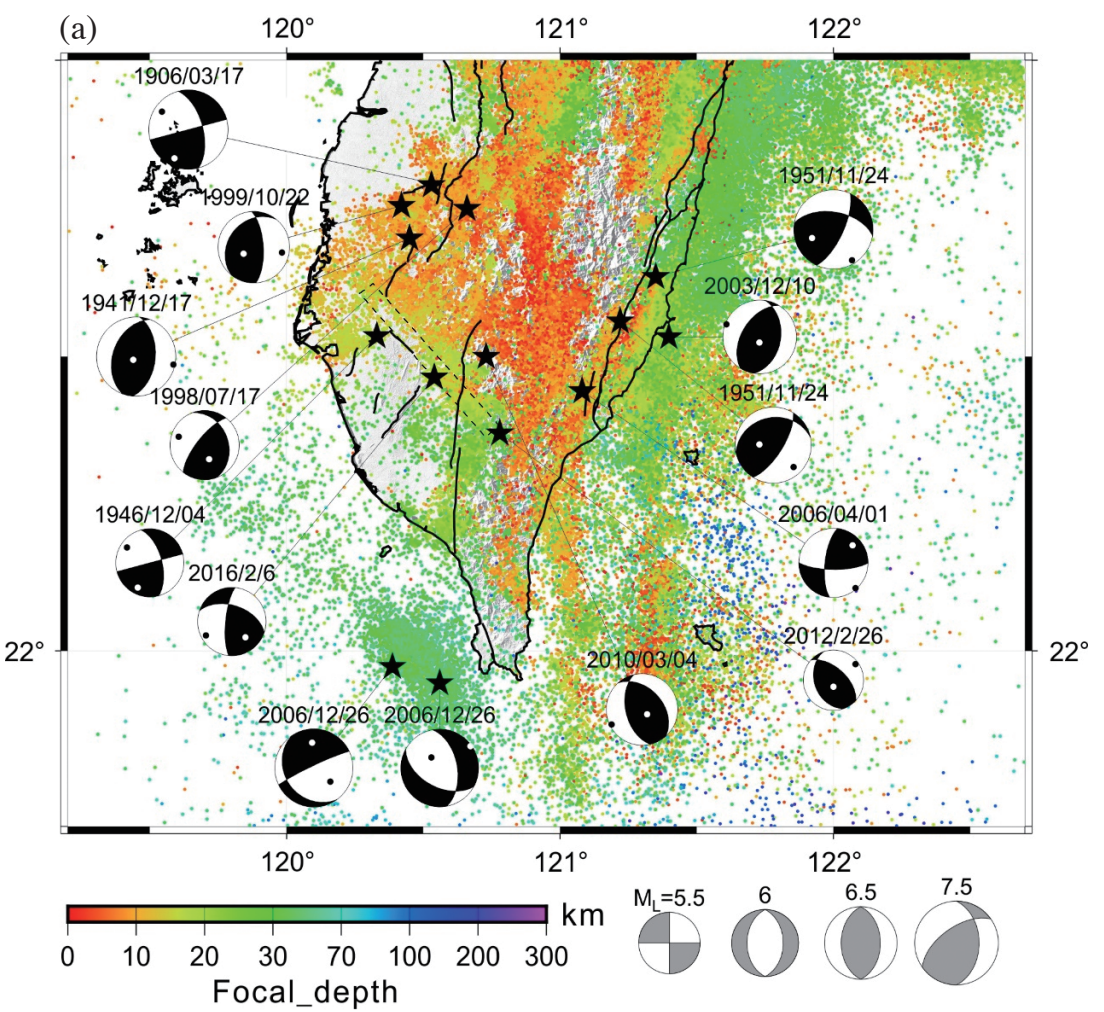

(b) NW

SE

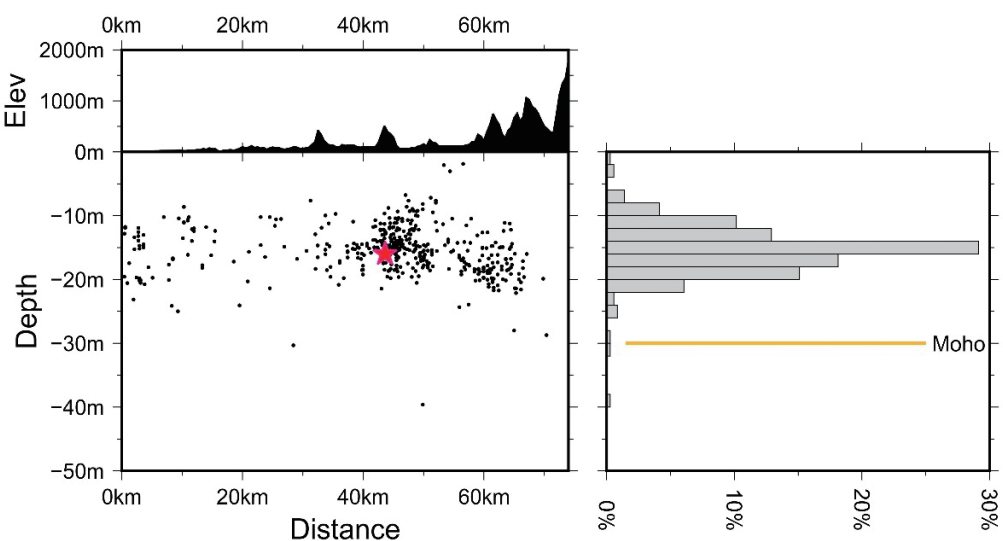

Fig. 2. (a) Distribution of background seismicity from 1991 - 2015 and historical disastrous earthquakes marked by black stars with focal mechanisms in Southern Taiwan. Color bars indicate the focal depths of earthquakes. Black dashed rectangle represented the location of Chishan Transform Fault Zone (CTFZ). Thick solid lines represent active faults (Lin et al. 2012). (b) Depth-frequency distribution of background seismicity along the Chihshan Transform Fault Zone (CTFZ). Earthquakes are located within a width of $5 \mathrm{~km}$ to the profile are projected on the cross section. Red star represents the Meinong earthquake. (Color online only) 
in Taiwan based on the records of Seismological Center, Central Weather Bureau (CWB), and only $\sim 31 \%$ of them are in SW Taiwan (Fig. 2). Clearly the dense seismicity with high seismogenic potential is located along the foldand-thrust belt of Western Foothills in Chiayi-Tainan area. However, it is worthy to note that frequent seismicity and moderate earthquakes also occur along the Chishan transfer fault zone (CTFZ), which is considered as a tear fault due to the different movement of thrust sheets (Deffontaines et al. 1997) or the structural inversion as a lateral ramp along the pre-existing Miocene NW-SE trending normal fault.

The ongoing collision is resisted by the Peikang High (Fig. 1), a Pre-Miocene basement, which acts as a buttress for advancing thrusts and creates a frontal thrust fault system parallel to the margin of the basement (Tsan and Keng 1968; Hu et al. 1997, 2001; Mouthereau and Petit 2003). At the eastern edge of the Peikang High, geometrical irregularity of the basement high is the most important factor that controls the geological development and the seismicity distribution for each compartment (Lin et al. 2003). The earthquakes are happened around the southeastern-edge of Peikang High because of the mechanically rigid basement is less seismogenic than the deformable western Foothills (Fig. 2). Southwestern Taiwan is located in the transition zone from the subduction to collision, the Central Range and Western Foothills are two major structural domains. The eastern Central Range domain mainly comprises of the Eocene-to-Miocene slate and pre-Tertiary highly metamorphic rocks (Fig. 3). In addition to the prevailing ductile folding structures, numerous late stage brittle normal faults exist within the Central Range which were interpreted as a result of gravitational collapse following the exhumation of thickened crust (Angelier et al. 1995; Crespi et al. 1996). The Western Foothills domain is consists of the Miocene shallow marine deposits and the Plio-Pleistocene foreland basin (Fig. 3). The foreland basin formed from rapid accumulated

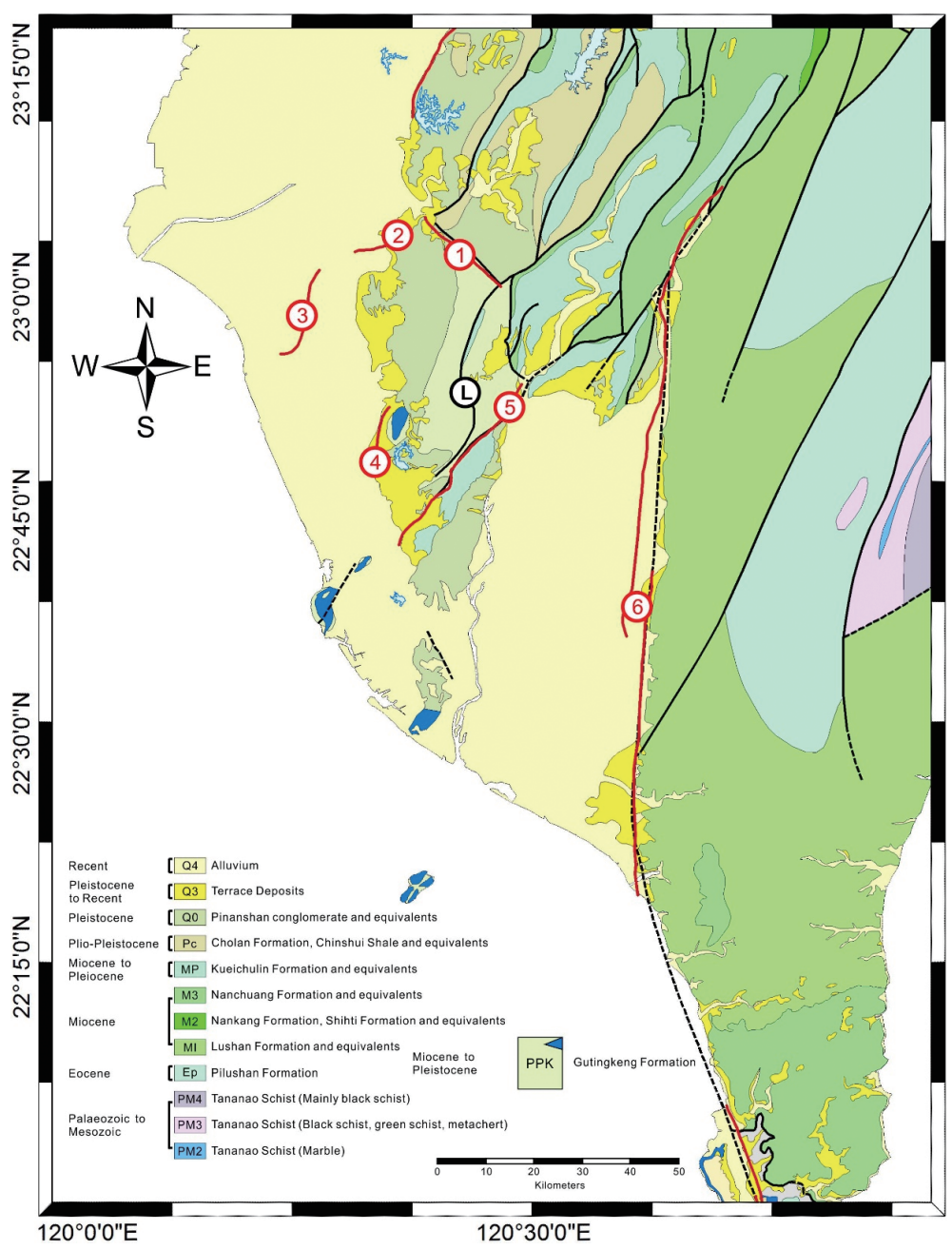

Fig. 3. Geological map with major faults and major structures in SW Taiwan. Color patches represent geological formations. Red and black lines indicate the major faults (Lin et al. 2012) in SW Taiwan. R numbers represents name of the major active faults: (1) Zuochen Fault, (2) Hsinhua Fault, (3) Hochiali Fault, (4) Siaogangshan Fault, (5) Chishan Fault, and (6) Chaochou Fault. Black line with symbol (1) indicates Longchuan Fault. (Color online only) 
deposits was interpreted as a response to the Plio-Pleistocene rapid mountain building and the lithospheric flexure due to the tectonic loading of mountain belt in the Central Range (Lin and Watts 2002; Lin et al. 2003). It is worthy to note that very thick mudstone of the Gutingkeng Formation (Plio-Pleistocene) widely distribute in SW Taiwan, which is relative softer in comparison with other geological formations in this region (Fig. 3). Overall, the Western Foothills of the fold-and-thrust belt comprises a series of imbricate west-vergent folds and thrusts, mixed with the pre-Tertiary basement-involved E-W trending normal faults (Lacombe et al. 1999; Mouthereau et al. 2002).

In terms of seismicity and focal depth of earthquakes in SW Taiwan (Fig. 2), high seismicity of shallow events with focal depths less than $15 \mathrm{~km}$ is found in Chiayi-Tainan area. The seismicity clearly delineates southeastern edge of Peikang-High, and four historical large earthquake events occurred in surrounding area, including the 1998 Rayli Earthquake and 1999 Chiayi earthquake (Fig. 2). In general, the earthquake focal depths start to get deeper and seismicity becomes less frequent on the southwestern side of the CTFZ. The CTFZ was interpreted as an active left-lateral transfer fault zone accommodating the differential westward motion of thrust sheets on both sides (Deffontaines et al. 1997; Lacombe et al. 2001). It is worthy to note that three historical earthquakes aligned along the CTFZ, including the recent Meinong event. It is surprising that low seismicity and frequent mid-crust events are observed in south-west of the CTFZ, which rheologically implies the upper crust is more or less aseismic in terms of the depth-frequency distribution of the earthquakes (Fig. 2b). However, the mid-crust level should have seismogenic potential for big earthquake in this area (Fig. 2).

The major active faults in SW Taiwan are the Zuochen, Hsinhua, Chishan, Chaochou, Hsiaokangshan (HKSF), and Hochiali Faults (Fig. 3). The Hsinhua fault (HWF) was significant ruptured by the disastrous Hsinhua Earthquake with the magnitude 6.8 in 1946. It is characterized by a rightlateral movement with the strike of $\mathrm{N} 70^{\circ} \mathrm{E}$. (Chang et al. 1947; Yu and Chen 1994; Yu et al. 1997; Shyu et al. 2005). The Hochiali fault (HCLF) is a near N-S trending thrust with the length about $12 \mathrm{~km}$ long (Sun 1964). Tsai (2013) analyzed the interseismic velocity profile and indicated a significant velocity discontinuity across the Hochiali fault, it may suggest the fault could be a seismogenic fault. Based on SAR interferometry (Fruneau et al. 2001; Huang et al. 2006, 2009) suggested that the uplift of Tainan tableland is associated of active folding controlled by west-vergent blind Tainan fault and east-vergent Hochiali fault. In addition, a variation of LOS rate across the Hochiali fault was revealed by PS-InSAR (Wu et al. 2013) deformation. It implies that the seasonality and hydro-geological condition also play a crucial role for the transient deformation (Huang et al. 2016a). The NE-SW trending Chishan fault (CSF) is interpreted as a reverse fault with a right-lateral component with a fault slip rate $\sim 7 \mathrm{~mm} \mathrm{yr}^{-1}$ in a $\mathrm{N} 50^{\circ} \mathrm{W}$ direction $(\mathrm{Hu}$ et al. 2007). It is a major fault with a large stratigraphic offset in the Western Foothills (Lacombe et al. 2001). In addition, an important active structure in our study area is the Lungchuan fault (LCF), although this fault is not defined as an active fault by Central Geological Survey (Fig. 3; Lin et al. 2012). It locates near the southern part of Zuochen fault, and has been recognized in association with the Lungchuan anticline (Hickman et al. 2002; Huang et al. 2004). On the base of seismic data, Huang et al. (2004) interpreted the N-S trending and east dipping Lungchuan fault as being connected to a décollement at about $6-7 \mathrm{~km}$ depth. Hickman et al. (2002) revealed that the horizontal velocity presents a discontinuity of nearly $2 \mathrm{~cm} \mathrm{yr}^{-1}$ across this fault. This fault is considered to be trigger in Meinong earthquake (Huang et al. 2016b).

\section{PROCESSING OF HIGH PRECISION CONTINUOUS GPS DATA}

The GPS survey provides accurate point positions to monitor the crustal deformation at the sites (Altamimi et al. 2002). Yu et al. (1997) started, and is arguably the first one, to study regional tectonics and fault activities in Taiwan in 1990. After 1999 Chi-Chi earthquake $\left(M_{w}=7.6\right)$, more than 150 new cGPS stations were established. These cGPS stations have been operated by various agencies, including the CWB, Institute of Earth Sciences, Academia Sinica (IESAS), Central Geological Survey (CGS), Ministry of the Interior (MOI), and other agencies since 1994. Currently, there are more than 500 cGPS stations in Taiwan are operated (Fig. 4).

\subsection{Continuous GPS Data Collection and Data Processing}

We collect 428 cGPS stations to process data for whole subnets in Taiwan (Fig. 4), only 87 cGPS daily solutions of subnets in southwestern Taiwan are used in this study. Raw data from each station is converted to Receiver-INdependent-Exchange (RINEX) format. Sometimes RINEX files may give wrong information or format errors because of incorrect initial setup for receivers. The most common problems are illogical or garbled data format, incorrect receiver or antenna types. The Translation, Editing, and Quality Check (TEQC) software developed by UNAVCO is employed to correct these problems before the data processing.

All cGPS data were processed by GAMIT/GLOBK software v.10.4 (Herring et al. 2010) with standard procedures. We processed a total of 428 Taiwan cGPS stations with time periods longer than 1.5 years and 25 International GNSS Service (IGS) stations by the same method in Tsai et al. (2015). Considering the computing capability and limitations of the number of sites for each subnet in GAMIT, we 
divided the 428 Taiwan cGPS stations into 16 sub-networks and chose additional 25 IGS stations as one subnet to constrain the result to the International Terrestrial Reference Frame 2008 coordinates (ITRF2008). In order to connect all subnets, we chose 5 local sites with longer data time span and good quality as common stations for all subnets. These common sites are S01R (Paisha, Penghu), S101 (Nankang, Taipei), S104 (Fushan, Taitung), LANY (Lanyu, Taitung), and HENC (Henchun, Pingtung) (Fig. 4). For the 25 IGS stations, we chose 18 sites with good data quality and longer time span in the Asia-Pacific region as reference stations for use stabilization in GLOBK, and the other 7 IGS sites are just for incorporated in the processing for better connection between IGS sites (Fig. 5 and Table 1). However, TSKB was not used for stabilization after 11 March 2011 off-Tohoku earthquake $\left(\mathrm{M}_{\mathrm{W}}\right.$ 9.0) to avoid the impact of post-seismic deformation.

\subsection{GPS Time Series and Common-Mode Error Correction}

The continuous GPS position time series can be described through the following model parameters (Nikolaidis 2002):

$$
\begin{aligned}
y\left(t_{i}\right)= & a+b t_{i}+c \sin \left(2 \pi t_{i}\right)+d \cos \left(2 \pi t_{i}\right)+e \sin \left(4 \pi t_{i}\right) \\
& +f \cos \left(4 \pi t_{i}\right)+\sum_{j=1}^{n_{g}} g_{j} H\left(t_{i}-T_{g j}\right)+\sum_{j=1}^{n_{h}} h_{j} H\left(t_{i}-T_{h j}\right) t_{i} \\
& +\sum_{j=1}^{n_{k}} k_{j} \exp \left[-\left(t_{i}-T_{k j}\right) / \tau_{j}\right] H\left(t_{i}-T_{k j}\right)+v_{i}
\end{aligned}
$$

Where $t_{i}$ for $i=1,2, \ldots \mathrm{N}$ are the daily solution epochs in units of years, and $H$ is the Heaviside step function. The first two terms are the site position, $a$, and linear rate (velocity field), $b$, respectively. Coefficients $c$ and $d$ describe the annual periodic motion, while $e$ and $f$ describe semi-annual motion. The next term corrects for any number $\left(n_{g}\right)$ of offsets, with the magnitudes $g$ at epochs $T_{g}$. The coefficients $h_{j}$ and $k_{j}$ are used for the post-seismic offset and exponential decay with the relaxation time $\tau_{j}$, respectively. The parameter $\tau_{j}$ is given different values for various stations and earthquake events to make the best time series fit. The final term $v_{i}$ is the model residual when the systematic errors are corrected, it presents a Gaussian distribution in the time domain. In addition, removing the systematic errors is also a method to effectively improve the data precision and identify signals in the time series.

Common-mode error is a kind of systematic error coming from poor constraint in data processing and regional mass redistribution (Dong et al. 2002). Wdowinski et al. (1997) pointed out the common-mode errors of all sites are the average from the summation of all station errors. Thus the common-mode error could be removed by subtracting the standard deviation of errors in three components of GPS position time series. Tabei and Amin (2002) also indicated the GPS time series errors approach the same value when the total number of stations for the estimation of common-mode errors reaches a certain quantity. In other words, removing common-mode error will not affect the velocity field result, but improve the data precision instead. The common-mode error can be obtained by stacking the GPS position time series model residuals for some specified stations with good data quality, uniformly disturbed, and long time period (Tsai 2013; Tsai et al. 2015).

In this study, the velocity of each cGPS site is estimated from the position time series through a model that removes outliers, color noise analysis, and common-mode error correction. At first, we transformed the coordinates from ITRF2008 Cartesian coordinates into ENU (east, north, and up components) coordinates for site movement. All outliers were identified by 3.5 times standard deviation (STD) and moving-average method (MA), which has an optimal window size of 30 days and shifts every 10 days (Tsai et al. 2015). More than $98 \%$ of the 428 cGPS stations show good data quality in position time series in which the removed outliers are less than $2 \%$ for whole data period. About $1 \%$ of the 428 cGPS stations demonstrate a very good data quality in which only $1 \%$ of the outliers are removed in position time series.

GPS time series noise is a power-law process, its powerspectrum, $P_{x}(f)$, can be expressed as the following equation:

$P_{x}(f)=P_{0}\left(\frac{f}{f_{0}}\right)^{k}$

Where $f$ is temporal frequency, $P_{0}, f_{0}$ are normalizing constant and $k$ is spectral index. The spectral index $k$ is used to define three kinds of color noise which is white noise $(k=$ 0 ), flicker noise $(k=-1)$, and random-walk noise (Brownian motion, $k=-2$ ). The noise can be a combination of different noise modes, i.e., white-noise-only model (WH), white noise + flicker noise model (FN), or white noise + random-walk noise model (RW). By stacking the power spectral densities from time series analysis residuals, we are able to estimate the spectral index to distinguish the noise characteristics (Williams 2003). By Stacking the 428 cGPS stations used in this study, the spectra indexes for the east, north, and vertical components are $-0.79,-0.81$, and -0.65 , respectively. This result indicates the noise model should be white noise plus flicker (FN) noise model, which is consistent with the results from previous studies (Zhang et al. 1997; Mao et al. 1999; Nikolaidis 2002; Yu et al. 2003; Tsai 2013; Tsai et al. 2015). We chose 65 relatively stable stations with data periods longer than 6.5 years spanning from 2007 - 2015 to estimate the common-mode error in the Taiwan area. By stacking these 65 fiducial sites the common-mode errors are 1.5, 1.3, and $3.1 \mathrm{~mm}$ in the east, north, and vertical components from 


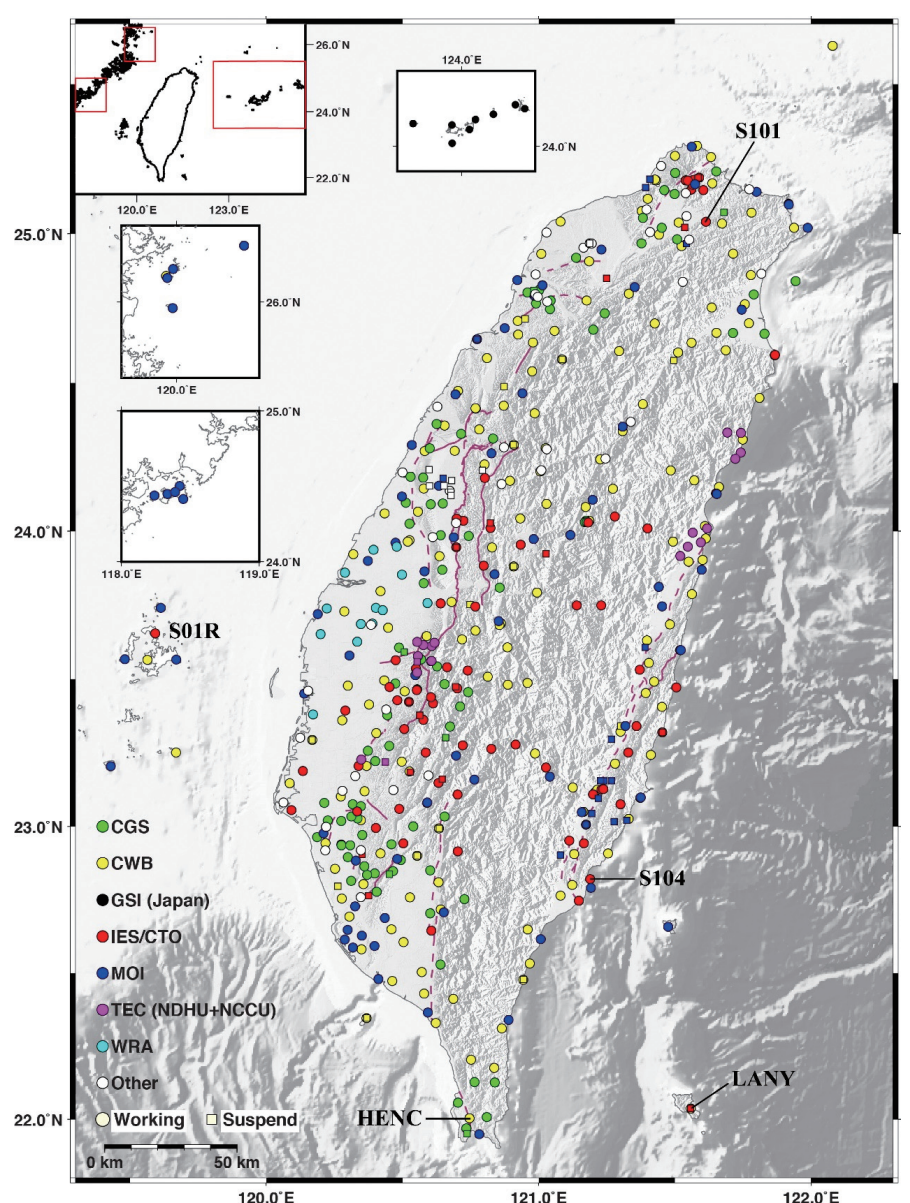

Fig. 4. Taiwan cGPS Network. Different color symbols indicate the operated cGPS stations by Central Weather Bureau (CWB), Institute of Earth Sciences, Academia Sinica (IESAS), Central Geological Survey (CGS), Ministry of the Interior (MOI), Geospatial Information Authority of Japan (GSI), Water Resources Agency, Ministry of Economic Affairs (WRA), Taiwan Earthquake Center (TEC), and others. Open squares indicate the operations are suspended. (Color online only)

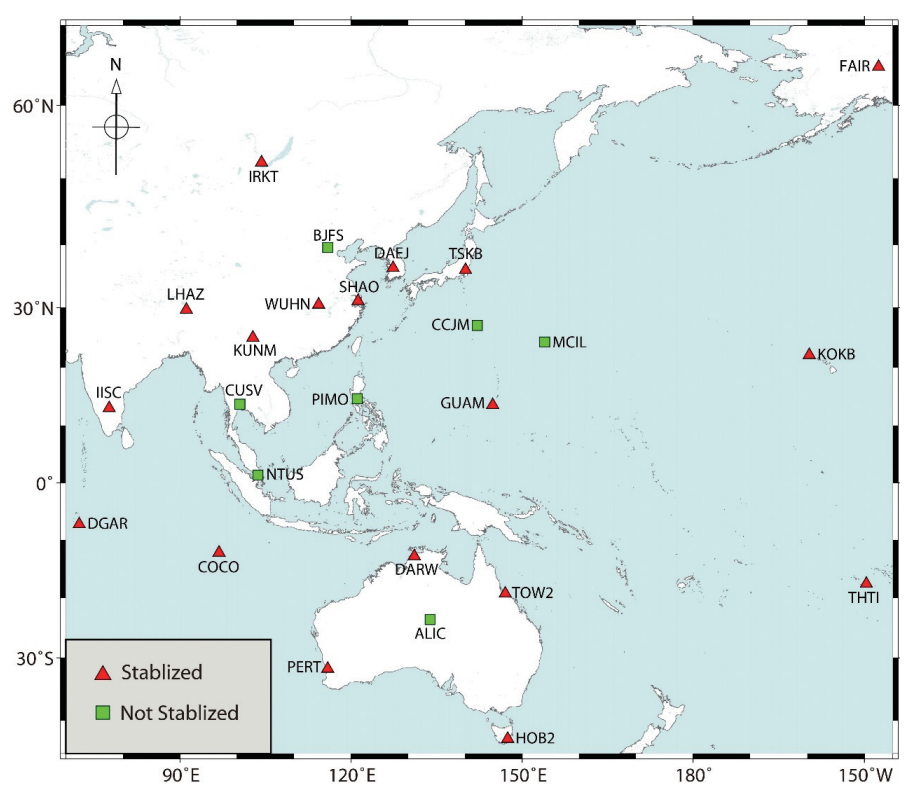

Fig. 5. Localities of 25 IGS stations for procession in GAMIT/GLOBK. Red triangles represent 18 IGS stations as reference stations for stabilization in GLOBK. Green squares represent 7 IGS stations for better connection between IGS sites. (Color online only) 
Table 1 . The coordinates of 25 IGS stations and their velocities under the reference frame ITRF2008 and WGS84 coordinate system.

\begin{tabular}{|c|c|c|}
\hline Site & IGS coordinate (m) & $\operatorname{Vel}\left(\mathbf{m} \mathbf{y r}^{-1}\right)$ \\
\hline $\begin{array}{c}\text { ALIC } \\
\text { Alice Springs, Australia }\end{array}$ & $\begin{array}{c}\text { X: }-4052052.14443 \\
Y: 4212836.06020 \\
Z:-2545105.39574\end{array}$ & $\begin{array}{l}\mathrm{V}_{\mathrm{x}}:-0.03955 \\
\mathrm{~V}_{\mathrm{y}}:-0.00505 \\
\mathrm{~V}_{\mathrm{z}}: 0.05410 \\
\end{array}$ \\
\hline $\begin{array}{c}\text { BJFS } \\
\text { Beijing Fangshan, China }\end{array}$ & $\begin{array}{c}\text { X: -2148744.23840 } \\
\text { Y: } 4426641.23131 \\
\text { Z: } 4044655.88015\end{array}$ & $\begin{array}{l}V_{x}:-0.03114 \\
V_{y}:-0.00579 \\
V_{z}:-0.00664\end{array}$ \\
\hline $\begin{array}{c}\text { CCJM } \\
\text { Chichijima, Ogasawara, Japan }\end{array}$ & $\begin{array}{l}\text { X: }-4488925.59258 \\
\text { Y: } 3483903.24061 \\
\text { Z: } 2887743.33495 \\
\end{array}$ & $\begin{array}{l}\mathrm{V}_{\mathrm{x}}: 0.02258 \\
\mathrm{~V}_{\mathrm{y}}: 0.02094 \\
\mathrm{~V}_{\mathrm{z}}: 0.00963 \\
\end{array}$ \\
\hline $\begin{array}{c}\text { COCO } \\
\text { Cocos (Keeling) Island, Astralia }\end{array}$ & $\begin{array}{l}\text { X: }-741950.61432 \\
\text { Y: } 6190961.66823 \\
\text { Z: }-1337767.90349\end{array}$ & $\begin{array}{l}\mathrm{V}_{\mathrm{x}}:-0.04481 \\
\mathrm{~V}_{\mathrm{y}}: 0.00465 \\
\mathrm{~V}_{\mathrm{z}}: 0.05003 \\
\end{array}$ \\
\hline $\begin{array}{c}\text { CUSV } \\
\text { Chulalongkorn, Bangkok, Thailand }\end{array}$ & $\begin{array}{c}\text { X: }-1132914.75163 \\
\text { Y: } 6092528.60229 \\
\text { Z: } 1504633.26631 \\
\end{array}$ & $\begin{array}{l}V_{x}:-0.02285 \\
V_{y}:-0.00761 \\
V_{z}:-0.00905 \\
\end{array}$ \\
\hline $\begin{array}{c}\text { DAEJ } \\
\text { Daejeon, Korea }\end{array}$ & $\begin{array}{c}\text { X: }-3120042.12938 \\
Y: 4084614.80845 \\
\text { Z: } 3764026.86441\end{array}$ & $\begin{array}{l}V_{x}:-0.02609 \\
V_{y}:-0.00990 \\
V_{z}:-0.00952\end{array}$ \\
\hline $\begin{array}{c}\text { DARW } \\
\text { Darwin, Australia }\end{array}$ & $\begin{array}{c}\text { X: }-4091359.25727 \\
\text { Y: } 4684606.56181 \\
Z:-1408579.71333 \\
\end{array}$ & $\begin{array}{l}\mathrm{V}_{\mathrm{x}}:-0.03510 \\
\mathrm{~V}_{\mathrm{y}}:-0.01411 \\
\mathrm{~V}_{\mathrm{z}}: 0.05804 \\
\end{array}$ \\
\hline $\begin{array}{c}\text { DGAR } \\
\text { Diego Garcia }\end{array}$ & $\begin{array}{l}X: 1916269.20141 \\
Y: 6029977.54025 \\
Z:-801719.74508 \\
\end{array}$ & $\begin{array}{l}\mathrm{V}_{\mathrm{x}}:-0.04336 \\
\mathrm{~V}_{\mathrm{y}}: 0.01857 \\
\mathrm{~V}_{\mathrm{z}}: 0.03288 \\
\end{array}$ \\
\hline $\begin{array}{c}\text { FAIR } \\
\text { Fairbanks, U.S.A. }\end{array}$ & $\begin{array}{l}X:-2281621.63936 \\
Y:-1453595.88878 \\
Z: 5756961.81403\end{array}$ & $\begin{array}{l}\mathrm{V}_{\mathrm{x}}:-0.02263 \\
\mathrm{~V}_{\mathrm{y}}:-0.00611 \\
\mathrm{~V}_{\mathrm{z}}:-0.00781 \\
\end{array}$ \\
\hline $\begin{array}{c}\text { GUAM } \\
\text { Dededo, Guam, U.S.A. }\end{array}$ & $\begin{array}{c}X:-5071312.73707 \\
Y: 3568363.54827 \\
\text { Z: } 1488904.33618 \\
\end{array}$ & $\begin{array}{l}\mathrm{V}_{\mathrm{x}}: 0.00611 \\
\mathrm{~V}_{\mathrm{y}}: 0.00737 \\
\mathrm{~V}_{\mathrm{z}}: 0.00522 \\
\end{array}$ \\
\hline $\begin{array}{c}\text { HOB2 } \\
\text { Hobart, Australia }\end{array}$ & $\begin{array}{c}\text { X: }-3950071.86875 \\
\text { Y: } 2522415.28748 \\
Z:-4311637.82332 \\
\end{array}$ & $\begin{array}{l}V_{x}:-0.03861 \\
V_{y}: 0.00786 \\
V_{z}: 0.04138 \\
\end{array}$ \\
\hline $\begin{array}{c}\text { IISC } \\
\text { Bangalore, India }\end{array}$ & $\begin{array}{l}\text { X: } 1337936.24039 \\
\text { Y: } 6070317.11455 \\
\text { Z: } 1427876.95761 \\
\end{array}$ & $\begin{array}{l}V_{x}:-0.04326 \\
V_{y}: 0.00084 \\
V_{z}: 0.03391 \\
\end{array}$ \\
\hline $\begin{array}{c}\text { IRKT } \\
\text { Irkutsk, Russia }\end{array}$ & $\begin{array}{l}\text { X: }-968332.52963 \\
Y: 3794425.40491 \\
Z: 5018167.71696\end{array}$ & $\begin{array}{l}V_{x}:-0.02575 \\
V_{y}:-0.00102 \\
V_{z}:-0.00383 \\
\end{array}$ \\
\hline
\end{tabular}

\begin{tabular}{|c|c|c|}
\hline Site & IGS coordinate $(\mathrm{m})$ & $\operatorname{Vel}\left(\mathrm{m} \mathrm{yr}^{-1}\right)$ \\
\hline $\begin{array}{c}\text { KOKB } \\
\text { Kauai, Hawaii, U.S.A. }\end{array}$ & $\begin{array}{l}X:-5543838.18710 \\
Y:-2054586.75005 \\
Z: 2387809.96360 \\
\end{array}$ & $\begin{array}{l}\mathrm{V}_{\mathrm{x}}:-0.00975 \\
\mathrm{~V}_{\mathrm{y}}: 0.06280 \\
\mathrm{~V}_{\mathrm{z}}: 0.03199 \\
\end{array}$ \\
\hline $\begin{array}{c}\text { KUNM } \\
\text { Kunming, China }\end{array}$ & $\begin{array}{l}X:-1281255.87628 \\
Y: 5640746.08677 \\
Z: 2682879.88796 \\
\end{array}$ & $\begin{array}{l}\mathrm{V}_{\mathrm{x}}:-0.03681 \\
\mathrm{~V}_{\mathrm{y}}:-0.00810 \\
\mathrm{~V}_{\mathrm{z}}:-0.01409 \\
\end{array}$ \\
\hline $\begin{array}{c}\text { LHAZ } \\
\text { LHASA, Tibet, China }\end{array}$ & $\begin{array}{l}X:-106941.68124 \\
Y: 5549269.84282 \\
Z: 3139215.07300 \\
\end{array}$ & $\begin{array}{l}\mathrm{V}_{\mathrm{x}}:-0.04589 \\
\mathrm{~V}_{\mathrm{y}}:-0.00787 \\
\mathrm{~V}_{\mathrm{z}}: 0.01415 \\
\end{array}$ \\
\hline $\begin{array}{c}\text { MCIL } \\
\text { Minamitorishima, Ogasawara, } \\
\text { Japan } \\
\end{array}$ & $\begin{array}{l}X:-5227187.91741 \\
Y: 2551880.66191 \\
Z: 2607618.04670 \\
\end{array}$ & $\begin{array}{l}\mathrm{V}_{\mathrm{x}}: 0.04040 \\
\mathrm{~V}_{\mathrm{y}}: 0.05993 \\
\mathrm{~V}_{\mathrm{z}}: 0.02175 \\
\end{array}$ \\
\hline $\begin{array}{c}\text { NTUS } \\
\text { Nanyang Technological } \\
\text { University, Singapore } \\
\end{array}$ & $\begin{array}{l}X:-1508022.85460 \\
Y: 6195576.62106 \\
Z: 148799.44415 \\
\end{array}$ & $\begin{array}{l}\mathrm{V}_{\mathrm{x}}:-0.02175 \\
\mathrm{~V}_{\mathrm{y}}:-0.00244 \\
\mathrm{~V}_{\mathrm{z}}:-0.01129 \\
\end{array}$ \\
\hline $\begin{array}{c}\text { PERT } \\
\text { Perth, Australia }\end{array}$ & $\begin{array}{l}\text { X: }-2368687.56746 \\
Y: 4881316.60203 \\
Z:-3341795.47716 \\
\end{array}$ & $\begin{array}{l}\mathrm{V}_{\mathrm{x}}:-0.04715 \\
\mathrm{~V}_{\mathrm{y}}: 0.00837 \\
\mathrm{~V}_{\mathrm{z}}: 0.05080 \\
\end{array}$ \\
\hline $\begin{array}{c}\text { PIMO } \\
\text { Quezon City, Metro Manila, } \\
\text { Philippines } \\
\end{array}$ & $\begin{array}{l}X:-3186293.78457 \\
Y: 5286624.28940 \\
Z: 1601158.33190 \\
\end{array}$ & $\begin{array}{l}\mathrm{V}_{\mathrm{x}}: 0.02291 \\
\mathrm{~V}_{\mathrm{y}}: 0.01415 \\
\mathrm{~V}_{\mathrm{z}}: 0.00636 \\
\end{array}$ \\
\hline $\begin{array}{c}\text { SHAO } \\
\text { Sheshan, China }\end{array}$ & $\begin{array}{l}X:-2831733.50160 \\
Y: 4675665.93124 \\
Z: 3275369.41167 \\
\end{array}$ & $\begin{array}{l}\mathrm{V}_{\mathrm{x}}:-0.03116 \\
\mathrm{~V}_{\mathrm{y}}:-0.01045 \\
\mathrm{~V}_{\mathrm{z}}:-0.01020 \\
\end{array}$ \\
\hline $\begin{array}{c}\text { THTI } \\
\text { Tahiti, French Polynesia }\end{array}$ & $\begin{array}{l}\text { X: }-5246415.73385 \\
Y:-3077259.75955 \\
Z:-1913842.04747 \\
\end{array}$ & $\begin{array}{l}\mathrm{V}_{\mathrm{x}}:-0.04169 \\
\mathrm{~V}_{\mathrm{y}}: 0.05162 \\
\mathrm{~V}_{\mathrm{z}}: 0.03308 \\
\end{array}$ \\
\hline $\begin{array}{c}\text { TOW2 } \\
\text { Townsville, Australia }\end{array}$ & $\begin{array}{l}X:-5054582.92694 \\
Y: 3275504.32723 \\
Z:-2091539.26365 \\
\end{array}$ & $\begin{array}{l}\mathrm{V}_{\mathrm{x}}:-0.03094 \\
\mathrm{~V}_{\mathrm{y}}:-0.01432 \\
\mathrm{~V}_{\mathrm{z}}: 0.05283 \\
\end{array}$ \\
\hline $\begin{array}{c}\text { TSKB } \\
\text { Tsukuba, Japan }\end{array}$ & $\begin{array}{l}\text { X: }-3957199.56519 \\
Y: 3310199.22782 \\
\text { Z: } 3737711.61149\end{array}$ & $\begin{array}{l}\mathrm{V}_{\mathrm{x}}:-0.00138 \\
\mathrm{~V}_{\mathrm{y}}: 0.00647 \\
\mathrm{~V}_{\mathrm{z}}:-0.00579 \\
\end{array}$ \\
\hline $\begin{array}{c}\text { WUHN } \\
\text { Wuhan, China }\end{array}$ & $\begin{array}{l}\text { X: }-2267749.57900 \\
Y: 5009154.19772 \\
\text { Z: } 3221290.62483\end{array}$ & $\begin{array}{l}\mathrm{V}_{\mathrm{x}}:-0.03185 \\
\mathrm{~V}_{\mathrm{y}}:-0.00808 \\
\mathrm{~V}_{\mathrm{z}}:-0.00995 \\
\end{array}$ \\
\hline
\end{tabular}

2007 - 2015, respectively. After common-mode error corrections we re-modeled all parameters for the 428 cGPS position time series. The results indicate the cGPS data precision was been further improved 1.9, 1.6, and $5.8 \mathrm{~mm}$ as compared to those without common-mode correction. Figure 6 shows the position time series with FN model and common-mode error corrected for the MLO1 station (Meinong, Kaohsiung) in the east, north, and up components, respectively. The blue solid circles and light gray bars indicate the observed daily solutions and their formal error. The pink line indicates model predictions. The dashed line denotes the offsets come from receiver, antenna update or coseismic displacements of earthquake events. The smoothing model predictions fit the observed cGPS position time series very well. The model results linear rates represent a more accurate velocity field.

\section{INTERSEISMIC AND COSEISMIC CRUSTAL DEFORMATION OF MEINONG EARTHQUAKE IN SW TAIWAN}

\subsection{The High Precision Velocity Field from 2007 - 2015}

We derived a 2007 - 2015 velocity field based on the time series analysis results from 428 cGPS stations in the Taiwan area, but we only use 87 cGPS stations in SW Taiwan for this study (Table 2). Figure 7 shows horizontal and vertical velocity filed with respect to S01R (Paisha, Penghu, see Fig. 1) located in the stable continent margin. The error ellipse on the tip of each velocity vector indicates $95 \%$ confidence interval of uncertainty for the horizontal velocity (Fig. 7a). It should be noted that stations with time periods less than 2 years and bad data quality are not shown. In 
general, the crustal motion shows nearly westward direction with rates of $32-46 \mathrm{~mm} \mathrm{yr}^{-1}$ in the southern section of Central Range, and reaches about $40 \mathrm{~mm} \mathrm{yr}^{-1}$ in Chiayi-Tainan area, then finally decreases to $0-5 \mathrm{~mm} \mathrm{yr}^{-1}$ in the Coastal Plain area. However, a significant of counterclockwise rotation of velocity filed from $\mathrm{E}-\mathrm{W}$ to $\mathrm{SW}$ to the south of the Hsinhua fault (Fig. 7a). It reaches about $50-55 \mathrm{~mm} \mathrm{yr}^{-1}$ in the Kaohsiung-Pingtung area and deviate about $25-30^{\circ}$ counterclockwise in the direction near the Kaohsiung-Pingtung coast, in which the tectonic extrusion plays an important role for counterclockwise block rotation (e.g., Hu et al. 2007; Ching et al. 2007). For vertical deformation, a significant subsidence occurred in coastal area of Chiayi and Pingtung area due to the over pumping of ground water for aquaculture usage (e.g., Hou et al. 2005; Lin et al. 2010; Hsieh et al. 2011; Tung and Hu 2012). The tectonic uplift are mostly located in the hill and mountainous area of the Western Foothills and Central Range. It is worthy to note that the significant uplift is observed in the Tainan-Kaohsiung area. The Tainan Tableland located west of the HCLF (Fig. 3) demonstrate a high uplift rate of $\sim 10 \mathrm{~mm} \mathrm{yr}^{-1}$ responsible for active fault-related folding process (Fruneau et al. 2001; Huang et al. 2006, 2009). In addition, the area bounded by the ZCF, SGSF, and CSF also show a significant tectonic uplift, which is also demonstrated by SAR interferometry and interpreted as active folding resulted from ramp duplex or high mobility of mud-core anticline (Hu et al. 2016).

\subsection{The Interseismic Crustal Strain Field}

Based on the 2007 - 2015 interseismic velocity field derived from GPS time series analysis, we use a new method (Hsu et al. 2009; Tsai 2013) to estimate the crustal strain rate in SW Taiwan. The new method is based on the traditional strain estimating hypothesis proposed by Shen et al. (1996) and Ward (1998) but give more constraints. In this study, we use the Voroni Cell to estimate the area of each cGPS site to give the optimal weighting for strain rate calculation. Furthermore, the strain rate interpolated by the velocity field gradient. In order to avoid the unreasonable strain rate result due to lack of cGPS velocity data, we only estimate strain rate when the interpolated middle point is surround by at least 4 cGPS sites. Figure 8 represents the results of interseismic principal strain and dilatation rates from 2007 2015 in SW Taiwan. In the Kaohsiung-Pingtung area, there is a shortening rate of about $-0.75 \sim-0.82 \mu$ strain $\mathrm{yr}^{-1}$ at the triangle region bounded by ZCF, CSF, and HCLF. No significant strain accumulated across the $\mathrm{CCF}$, thus the $\mathrm{CCF}$ is more like a strain boundary of compression to extension. The maximum extension rate in the $\mathrm{E}-\mathrm{W}$ direction is observed to the eastern side of CCF (i.e., the southern section of the Central Range), it could be related to double-vergence popup structure (Malavieille and Trullenque 2009). In general, the high strain rate accumulation across the major structures of fold-and-thrust belt, it seems that the en-echelon faultrelated foldings controlled by the NE-SW décollement ramp play an important role of gradient of deformation from north to south (Hu et al. 2016). The shear strain rate also shows the similar pattern. In addition, the area from Chishan to Kaohsiung area, the high shear strain rate could be attributed to the right-lateral shearing continuing to off-shore area to accommodate tectonic extrusion of this area. Based on analysis of the geomorphological features, Shyu et al. (2005) delineated several NE-SW striking discontinuous and distributed lineaments which are also associated with the right-later shearing of potential seismogenic faults in this area. It might be also related to NE-SW striking steep lateral ramp at depth under tectonic inversion of inherited normal fault system.

\subsection{The Baseline Analysis}

To analyze the length variation of the baseline between two cGPS sites across the fault also provide the information about fault activity and how strain is accommodated across the active structures. In order to understand the precision of baseline data, the formalism proposed by Savage and Prescott (1973) is utilized to describe the precision of the epoch in GPS measurements as a function of baseline length:

$\sigma_{L}=\sqrt{a^{2}+b^{2} \cdot L^{2}}$

Where $\sigma_{L}$ is the standard deviation, $L$ is the baseline length, $a$ and $b$ are the constants and length dependent source of error, respectively. In addition, the precision is much worse in vertical component (Savage and Prescott 1973). Therefore, the estimation of baseline variation only use north and east components of cGPS sites with good data quality such as complete data period and no sites effects.

Taking the data quality into account, totally 26 baselines were used in this study. The baseline length variation and its uncertainty estimated by error propagation method (Leick 1989; Strang and Borre 1997) can be described by following equations:

$$
\begin{aligned}
& L=\sqrt{\left(D_{E 1}-D_{E 2}\right)^{2}+\left(D_{N 1}-D_{N 2}\right)^{2}} \\
& \operatorname{Std}(L)=\sqrt{\operatorname{Std}\left(D_{E}\right)^{2}+\operatorname{Std}\left(D_{N}\right)^{2}}
\end{aligned}
$$

Here $L$ represents the length of baseline $D_{E 1}, D_{E 2}, D_{N 1}, D_{N 2}$ represent the displacements (daily solution) of east and north components for GPS sites 1 and 2. The $\operatorname{Std}(L)$ is uncertainty of baseline length. Wherein, $\operatorname{Std}\left(D_{E}\right)$ and $\operatorname{Std}\left(D_{N}\right)$ are uncertainties in east and north components of GPS data for two different stations, respectively. It can be represented as the following: 
$\operatorname{Std}\left(D_{E}\right)=\sqrt{\operatorname{Std}\left(D_{E 1}\right)^{2}+\operatorname{Std}\left(D_{E 2}\right)^{2}}$

$\operatorname{Std}\left(D_{N}\right)=\sqrt{\operatorname{Std}\left(D_{N 1}\right)^{2}+\operatorname{Std}\left(D_{N 2}\right)^{2}}$

To estimate the slope of baseline length in time series with simple linear regression, the slope value indicates the contractional or extensional crustal deformation between two cGPS stations. Totally 26 baseline length variations across different fault systems are calculated in SW Taiwan from 2007 - 2015 (Fig. 9), which positive value indicates extension and negative ones represent shortening.

Most of baselines present the shortening with the rate from $-0.8 \sim-26 \mathrm{~mm} \mathrm{yr}^{-1}$ in Kaohsiung-Pingtung area. This is consistent with the maximum principal strain and the relative baseline shortening and the length of the baseline calculated. Some baselines demonstrate the extension with the rate about $0.2-8.2 \mathrm{~mm} \mathrm{yr}^{-1}$, in which the significant extension of 8.2 and $4.1 \mathrm{~mm} \mathrm{yr}^{-1}$ is observed along the baselines GS59-GS58 and LAOL-DAJN in south Central Range, respectively. It is consistent with the extensional strain rate observed in south Central Range. In addition, the significant extension of baselines ZEND-CTOU and CTOU-BANP with the rate of 3.4 and $6.8 \mathrm{~mm} \mathrm{yr}^{-1}$ is also observed near Kaohsiung-Pingtung coastal area, which a counterclockwise rotation of GPS velocity filed is observed.

\subsection{The $M_{w} 6.4$ Meinong Earthquake and Coseismic Crustal Deformation}

A disastrous $\mathrm{M}_{\mathrm{W}}$ 6.4 Meinong Earthquake occurred at the Kaohsiung area in SW Taiwan with the focal depth about $14.6 \mathrm{~km}$ on 6 February 2016. Figure 10 shows background seismicity from 2007 - 2015, historical earthquakes with focal mechanisms, main shock and aftershocks of the Meinong earthquake relocated by 3D velocity model (Wu et al. 2007). No known surface fault system is related to this event; thus a subsurface blind fault system is attributed to this seismogenic fault. The distribution of the aftershocks was clustered at two different regions with different depths. One group of aftershocks with the shallower depths of $\sim 5-15 \mathrm{~km}$ located at south region of the main shock and the north part of the surface trace of CSF. The other group of aftershocks with focal depths about deeper than $20 \mathrm{~km}$ located near Tainan area. In the past, 3 big historical earthquakes occurred near the Meinong event, which were 1946 Hsinhua earthquake, $2010 \mathrm{Ji}$ ashian earthquake, and 2012 Wutai earthquake. Interestingly, the P-axis of the Hsinhua event orients in NW direction parallel to the convergence direction of the Philippine Sea plate, however the P-axis of Jiashian, Wutai, and Meinong events trend in NE with a high angle to the convergence direction, it implies that stress permutation of $\sigma_{1}-\sigma_{2}$ or $\sigma_{2}-\sigma_{3}$ happens due to the close stress magnitude of principal stress, a

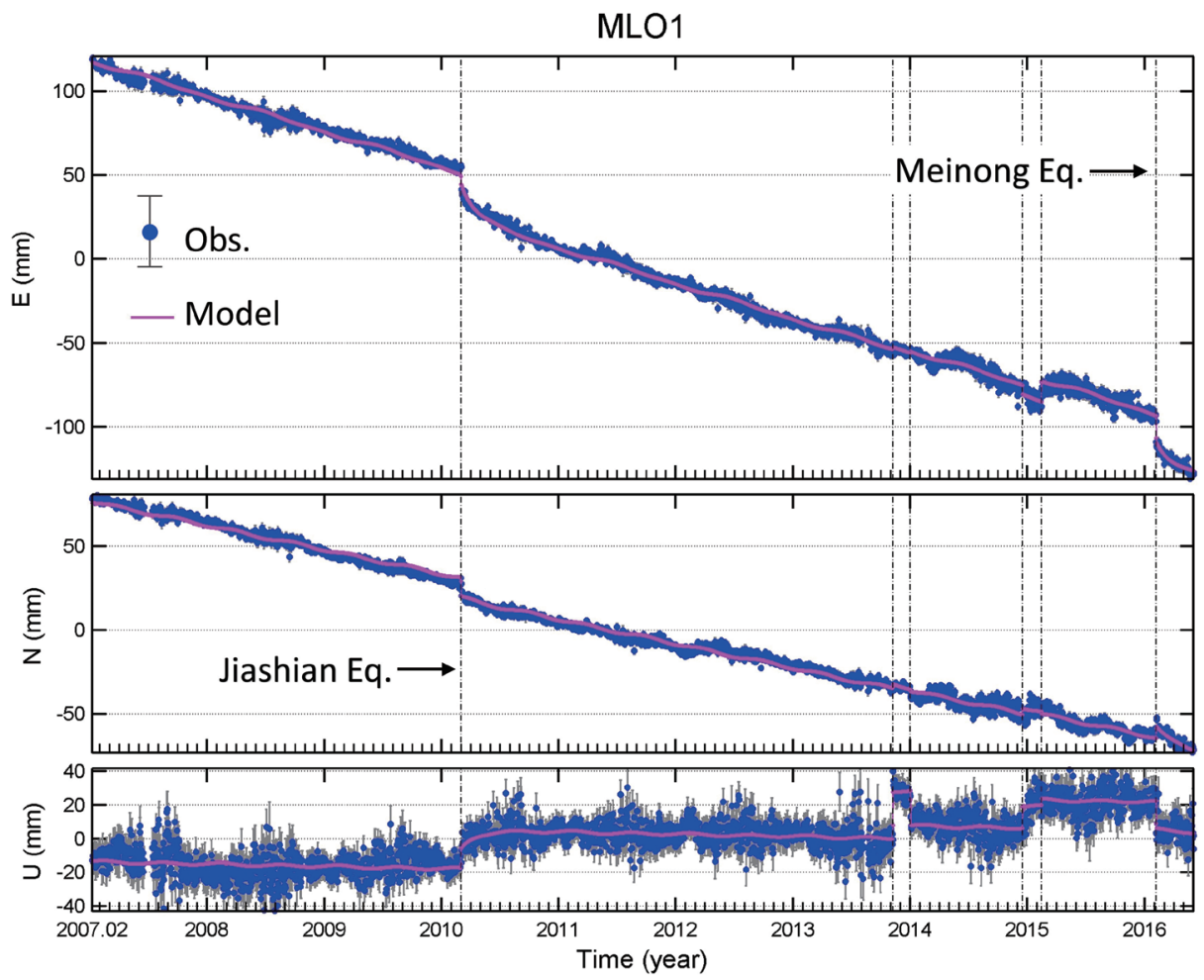

Fig. 6. Position time series at MLO1 station (Meinong, Kaohsiung) in east, north, and up components, respectively. Blue solid circles and light gray bars indicate the observed daily solutions and formal errors. Pink lines indicate model predictions. Dashed lines denote the offsets from update of receiver and antenna or coseismic displacements of earthquake events. (Color online only) 
Table 2. Interseismic velocity field of SW Taiwan. $V_{h}$ and $V_{u}$ represent horizontal and vertical velocity with respect to $S 01 R$.

\begin{tabular}{|c|c|c|c|c|c|c|c|c|c|c|c|}
\hline Site & $\left(^{\circ}\right)$ & $\left({ }^{\circ}\right)$ & $\left(\mathbf{m m} \mathbf{y r}^{-1}\right)$ & $\mathbf{z i}\left({ }^{\circ}\right)$ & (Imim y & Site & ) & Lat. & $\mathbf{V}_{\mathrm{h}}(\mathbf{m m}$ & $\mathbf{A z}$ & $\mathbf{V}_{\mathrm{u}}(\mathbf{m} \mathrm{I}$ \\
\hline KND & 120.35726 & .80331 & $7+11$ & $2578+130$ & $1+20$ & OKN & 120.13488 & 23.18838 & $2.8 \pm 0.4$ & $250.9 \pm 10.6$ & $-6.1 \pm 1.6$ \\
\hline BANP & 0.30540 & 69313 & $4.0 \pm 1.3$ & $244.0=$ & .5 & 33 & 08 & 23 & .1 & 23.5 & 3.8 \\
\hline BKBL & 120.06339 & 23.08140 & +08 & $254.7 \pm 35.9$ & $-7.0 \pm 3.1$ & HSR4 & 120.34697 & 22.75 & $60.1 \pm 1.2$ & $259.6 \pm 12.3$ & $-12.7 \pm 3.7$ \\
\hline CHIE & 120.3 & 19 & .6 & .4 & 2 & $\mathrm{~T}$ & 78 & 2 & 0.5 & 0.6 & 2 \\
\hline CHIK & 120.06340 & 23.08140 & 0.9 & 249 . & -7 & ASH & 120.28835 & 22.61449 & 0.5 & $=11.0$ & 2.0 \\
\hline CHKU & 120. & 23.0 & 4 & .2 & -4 & $\mathrm{U}$ & 12 & 22.8 & 6 & 27 & .5 \\
\hline $\mathrm{CISH}$ & 120.48123 & 22.8 & 49.7 & .1 & .8 & AWN & 120. & 23.17 & .9 & 275 & 3.4 \\
\hline CK01 & 120.21046 & 22.97589 & 70 & 95.0 & 226 & $\mathrm{AFO}$ & 120.5 & 231 & 30.9 & 28.6 & 5 \\
\hline CKGM & 120.22006 & 22.99883 & $9.8 \pm 2.1$ & $251.6 \pm 38.6$ & $3.0 \pm 8.3$ & $\mathrm{AOL}$ & 120.68729 & 22. & $54.4 \pm 1.1$ & $=1.5$ & 4.0 \\
\hline CKSV & 120.2 & 2 & $6+5-2$ & $1+$ & $3.4 \pm 1.7$ & $\mathrm{~F}$ & 1 & 2 & 5 & .9 & 8 \\
\hline CLON & 120.57960 & 22.43005 & $55.2 \pm 0.6$ & $269.4 \pm$ & -15 & $\mathrm{~N}$ & 120. & 22.8 & 28. & $257.6 \pm 24.1$ & 8.3 \\
\hline CTOU & 120.27784 & 22.75468 & T1. 1 - 0.0 & (1) & . & LIKN & 120.52790 & 22.75861 & $56.3 \pm 1.3$ & 7.0 & 4.4 \\
\hline DALO & 120.39777 & 22.59261 & $49.5 \pm 4.1$ & $248.3 \pm 86.6$ & .5 & $\mathrm{C}$ & 120.36907 & 22.34667 & $58.1 \pm 1.4$ & 4.0 & $2.0 \pm 6.1$ \\
\hline DANI & 120 & 2. & $13.7 \pm 2.9$ & 262.5 & 5.4 & $\mathrm{NCH}$ & 120 & 22.9 & 25.3 & .3 & 8 \\
\hline DASU & 120.43542 & 22.68794 & $51.1 \pm 1.8$ & $262.9 \pm 12.7$ & $-13.3 \pm 8.1$ & AJA & 120.65 & 22. & $59.2 \pm 0$ & $270.2 \pm$ & $2.1 \pm$ \\
\hline DONA & 120.7 & 22.91 & $55.7 \pm$ & 2 & 10 & 0 & 5 & 227 & $3+3$ & .2 & 13. \\
\hline FALI & 120.59360 & 22.36525 & $554 \quad 0$ & & $07+26$ & $\mathrm{O} 1$ & 120.55400 & 22.90000 & $53.1 \pm 0.6$ & $268.3 \pm 1.2$ & $0.0 \pm 2.3$ \\
\hline FONG & 120.3510 & 22.62775 & $51.9 \pm 1.9$ & $247.0 \pm 41.3$ & $-0.2 \pm 8.2$ & NANK & 120.27439 & 23.10199 & $6.2 \pm 0.6$ & $270.0 \pm 3.7$ & $1.2 \pm 2.4$ \\
\hline S & 120. & 23.0 & $70^{\circ}$ & 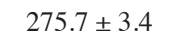 & S & 21 & 3 & 2 & $J$ & 9.3 & $0.6 \pm 6.2$ \\
\hline GS28 & 120.21358 & 23.07986 & $6.3 \pm 0.6$ & $268.2 \pm 4.7$ & $-3.3 \pm 3.9$ & $\mathrm{NCKU}$ & 120.27581 & 22.93845 & $23.9 \pm 0.7$ & $266.4 \pm 2.7$ & $4.9 \pm 2.2$ \\
\hline 9 & 1 & 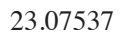 & 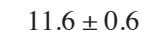 & $263.6 \pm 4.8$ & & N & 8 & 2 & $38.3 \pm 0.6$ & & \\
\hline GS30 & 120.22612 & 23.02032 & $12.2 \pm 0.4$ & $273.3 \pm 2.3$ & & JJOU & 120.57141 & 22.50389 & $57.8 \pm 0.5$ & 268.5 & -10.3 \\
\hline GS31 & 120.27588 & 23.0 & 17 & 26 & -1 & $\mathrm{~L}$ & 12 & 23 & 46 & 27 & 2.0 \\
\hline GS32 & 120.33584 & 23.02714 & $20.7 \pm 0.4$ & $259.7 \pm 4.2$ & $2.1 \pm$ & TUN & 120.45968 & 22.64985 & $58.4 \pm 1.0$ & $259.6 \pm$ & $1.0 \pm 4.0$ \\
\hline GS33 & 120. & 22. & $10.7 \pm 0.4$ & 26 & -2 & $S$ & 12 & 23 & 3 & 28 & 5 \\
\hline GS34 & 120.27632 & 22.93612 & $24.4 \pm 0.5$ & $267.2 \pm 1.7$ & $3.9 \pm$ & S012 & 120.48826 & 23.05947 & $35.2 \pm 0.5$ & 272.6 & 1.9 \\
\hline GS35 & 120.30849 & 22.93581 & $24.6 \pm$ & 265 & 8 & 06 & 12 & 23.05 & 17 & 25 & .7 \\
\hline GS45 & 120.7 & 22.75250 & $6.8 \pm 0$ & (2) & - & & 1 & 9 & $46.9 \pm 0.6$ & - & $0.5 \pm 2.0$ \\
\hline GS46 & 120.63950 & 22.52970 & $56.9 \pm 0.5$ & $271.4 \pm 0.8$ & $2.9 \pm 2.7$ & $23 \mathrm{R}$ & 120.60617 & 22.64498 & $55.2 \pm 0.6$ & $269.6 \pm 0.5$ & $2.6 \pm 2.3$ \\
\hline GS5 & 1 & 23. & $47.1 \pm 0.6$ & & & $E$ & 1 & 22 & 4 & 24 & \\
\hline GS52 & 120.65472 & 23.03402 & $50.0 \pm 0.6$ & $268.9 \pm 0.9$ & $9+24$ & AND & 120.6 & 22.71727 & $58.9 \pm 0.5$ & $270.2=$ & 5.1 \\
\hline GS53 & 120.39831 & 22.83998 & & & & N & 1 & 22 & & 2 & \\
\hline GS54 & 120.45209 & 22.83710 & $53.9 \pm 1.2$ & $265.7 \pm 5.2$ & $-0.5 \pm 4.8$ & GAN & 120.34965 & 22.58127 & $50.7 \pm 0.5$ & $246.8 \pm 10.4$ & $-2.8 \pm 2.3$ \\
\hline GS55 & 120.60224 & 22.85069 & $55+06$ & $2604+08$ & $10 \Omega$ & IWA & 120.34781 & 23.02 & $21.3 \pm$ & 4 & $57+3$ \\
\hline GS56 & 120.60173 & 22.70388 & $56.2 \pm 0.7$ & $269.9 \pm 0.5$ & $0.5 \pm 2.0$ & & 120.76419 & 23.15934 & $39.3 \pm 0.6$ & $276.0 \pm 3.7$ & $10.1 \pm 2.2$ \\
\hline GS73 & 120.35303 & 22.97111 & $240+$ & $257.5 \pm$ & $2.6 \pm$ & ANC & 120 & 23.18684 & $32.6=$ & .0 & 2.6 \\
\hline GS74 & 120.45980 & 22.93916 & $39.8 \pm 2.0$ & $261.6 \pm 16.6$ & 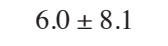 & WDAN & 120.5 & 22.60 & 53. & 26 & .9 \\
\hline GS75 & 120.49412 & 22.88556 & $50.7 \pm 2.5$ & $264.6 \pm$ & $-1.1 \pm$ & HES & 120.34 & 22.91 & $31.7 \pm$ & $250.5 \pm$ & $-6.4 \pm 6.9$ \\
\hline GS76 & 120.37070 & 22.83527 & .2 & 25 & 11.6 & HD & 120.34770 & 22.91918 & 32 & 0.9 & 9.3 \\
\hline GS77 & 120.4 & 22.77 & $56.8 \pm 2.1$ & $258.6 \pm$ & -4 & XIAN & 120 & 23 & .2 & $269.5=$ & 10.4 \\
\hline GS78 & 120.46561 & 22.84779 & $48.2 \pm 2.9$ & $264.0 \pm 17.3$ & $4.5 \pm 9.6$ & YJLO & 120.46683 & 23.12360 & $31.6 \pm 1.9$ & $279.1 \pm 17.4$ & $1.3 \pm 7.2$ \\
\hline GS79 & 120.29961 & 22.89573 & 28 . & 258 & 2.3 & YSAN & 120.08598 & 23.14655 & 0.4 & 173.7 & $-6.0 \pm 2.1$ \\
\hline GS80 & 120.36064 & 86419 & 2.9 & $6 \pm 37.6$ & $10.3 \pm 10.7$ & ZEND & 120.21756 & 22.94327 & 14 & 26 & 6. \\
\hline
\end{tabular}

$\begin{array}{llllll}\text { GS81 } & 120.31207 & 22.81486 & 34.7 \pm 3.2 & 267.2 \pm 11.2 & -10.4 \pm 15.4\end{array}$ 

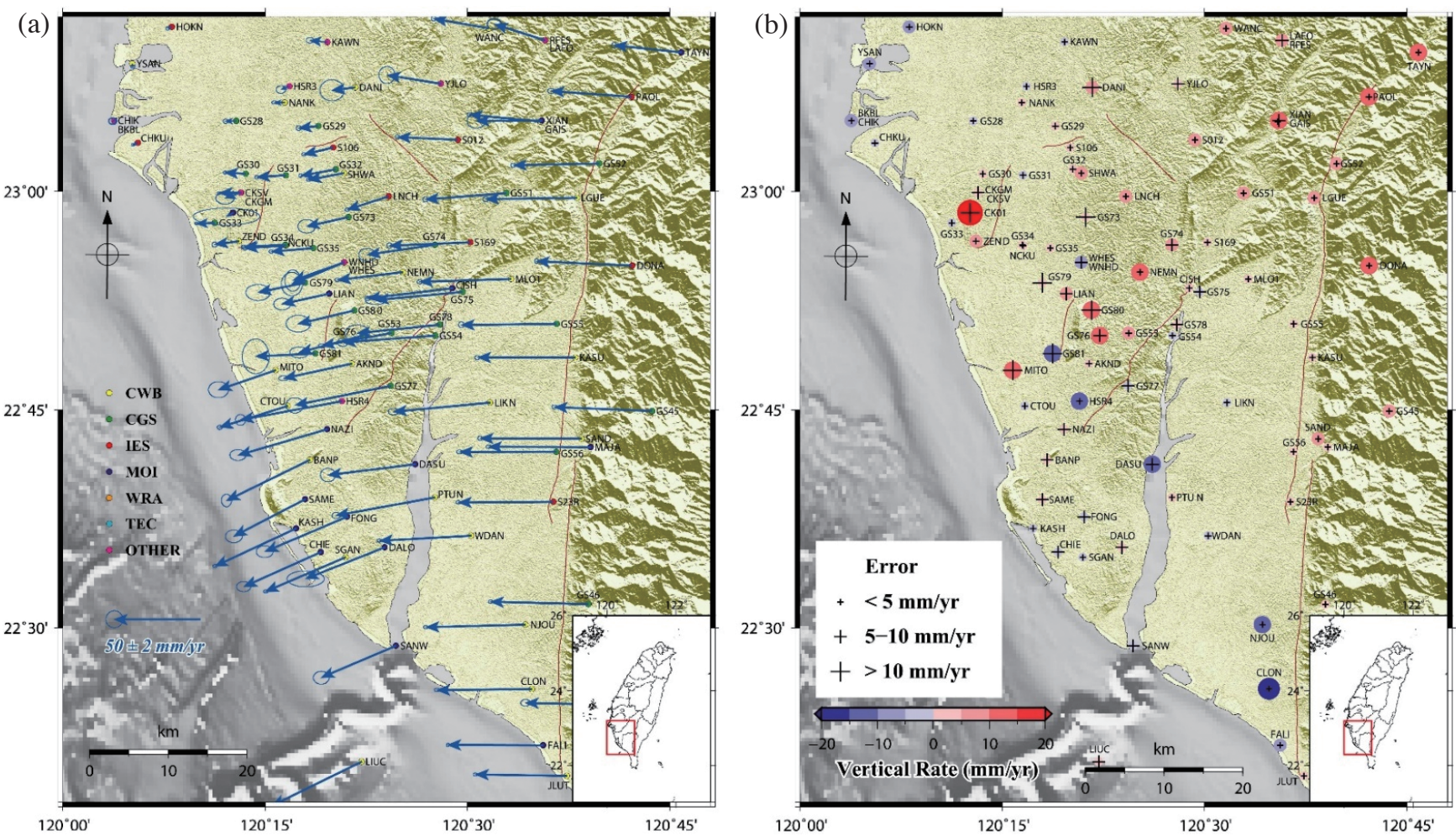

Fig. 7. (a) Horizontal velocities of cGPS stations in SW Taiwan w.r.t. Paisha, Penghu (S01R, locality see Fig. 1). Blue arrows show velocity field with $95 \%$ confidence error ellipse at the tip of velocity vector. (b) Vertical velocities of cGPS stations in SW Taiwan w.r.t. S01R. Red and blue circles indicate uplift and subsidence, respectively. Dark-red lines indicate the surface traces of major active faults (Lin et al. 2012). (Color online only)

(a) Principal Strain \& Dilatation rates

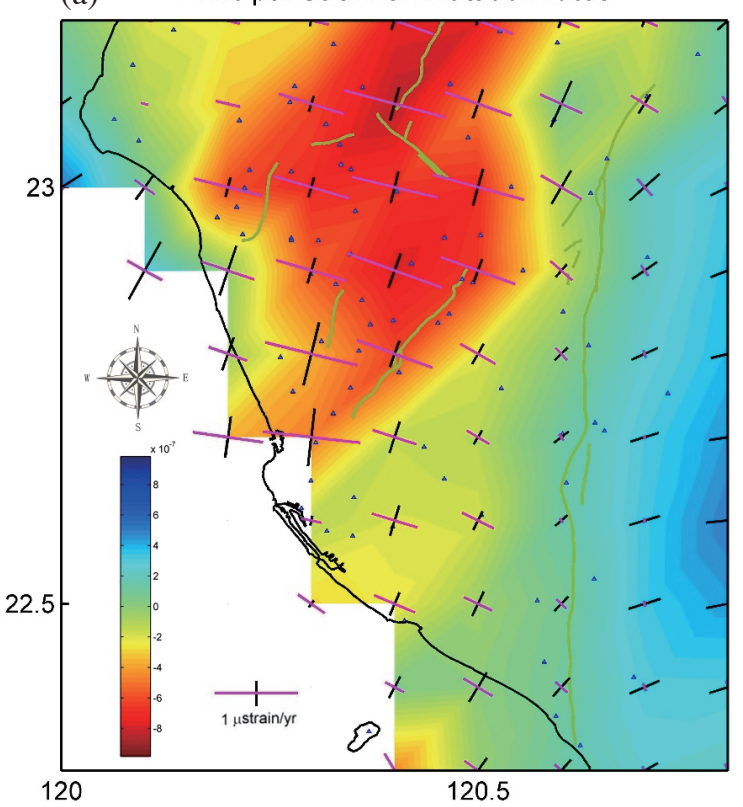

(b)

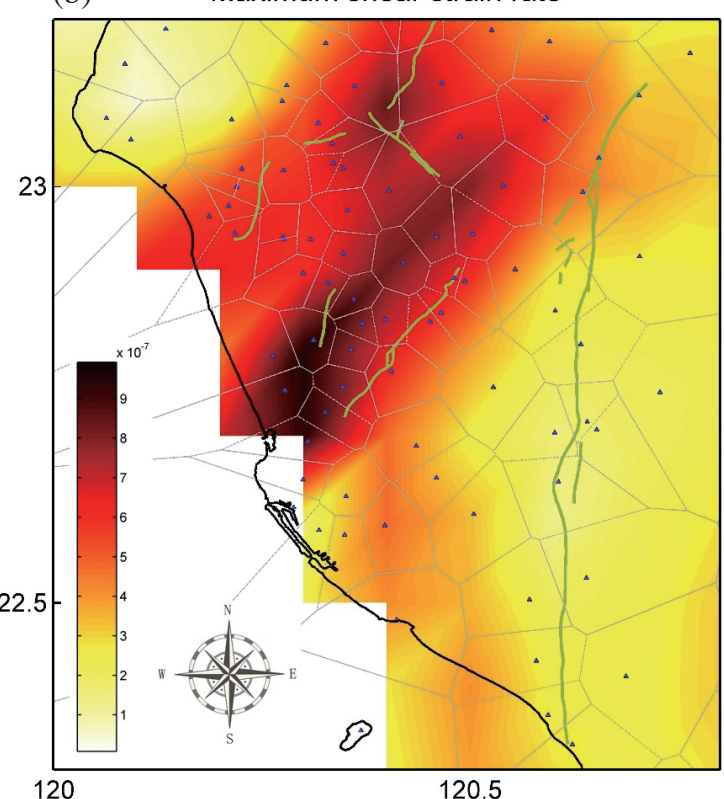

Fig. 8. (a) Interseismic principal strain and dilatation rates from 2007 - 2015 in SW Taiwan. Pink and black bars indicates the principal axes for shortening and extension. Color contour represents the dilatation rate. (b) Maximum shear strain rate filed in SW Taiwan. Colored contour represents the value of maximum shear rate. Gray dash lines describe the edge of each Voroni Cell used for strain calculation. Green line indicates the major active faults (Lin et al. 2012) and solid triangles indicate the cGPS stations. (Color online only) 

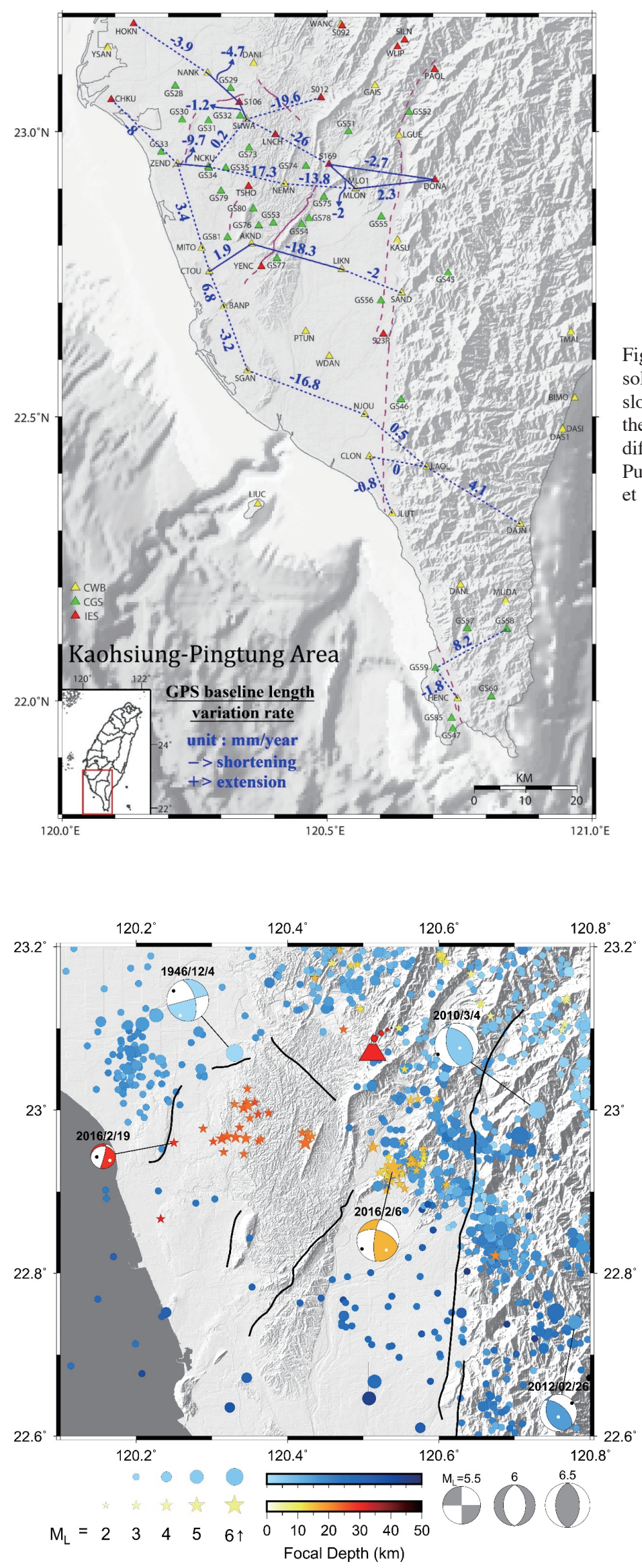

Fig. 9. Baseline variations with time in Kaohsiung-Pingtung area. Blue solid and dashed lines indicate baseline of cGPS used in this study with slope values of baseline change with times. Blue sloid lines represent the time series of 8 baselines change shown in Fig. 13. Triangles with different colors indicate the cGPS stations of different institutions. Purple solid and dashed lines represent active faults in study area (Lin et al. 2012). (Color online only)
Fig. 10. Background seismicity from 2007 - 2015 with historical disastrous earthquakes cool-color-coded with focal depth. Warm-color-coded stars with focal depth represent the Meinong earthquake and aftershocks relocated by 3D velocity model (Wu et al. 2007). Solid and open dots shown on focal mechanisms represent $\mathrm{P}$ and $\mathrm{T}$ axes, respectively. Big red marker is the location of mud volcano activated during the Meinong event. (Color online only) 
common phenomenon in brittle tectonics ( $\mathrm{Hu}$ and Angelier 2004). An alternative interpretation of NE trending of P-axis of focal mechanism is that the mountain-parallel southwestward movement dominated in Central Range and inner western Foothills could result in a NE-SW compression to reactivate the inherited NW-SE or E-W trending normal faults as a lateral ramp for these three events.

We collected the data 5-days before and after earthquake for processing with final orbit ephemeris to obtain the higher precision coseismic displacements. The coseis- mic value is interpolated to the earthquake occurred time by mean value of the daily solution 5-days before and after the Meinong earthquake. Figure 11 shows the coseismic displaces calculation by GPS time series of MLO1 station in east, north, and up components, respectively. The blue dots with the bar indicates the daily solution and its formal error. The gray dash line indicates the occurred time of the Meinong earthquake. The red and pink line indicate mean value of 5-days daily solution before and after the earthquake. Figure 12 represents the coseismic deformation in
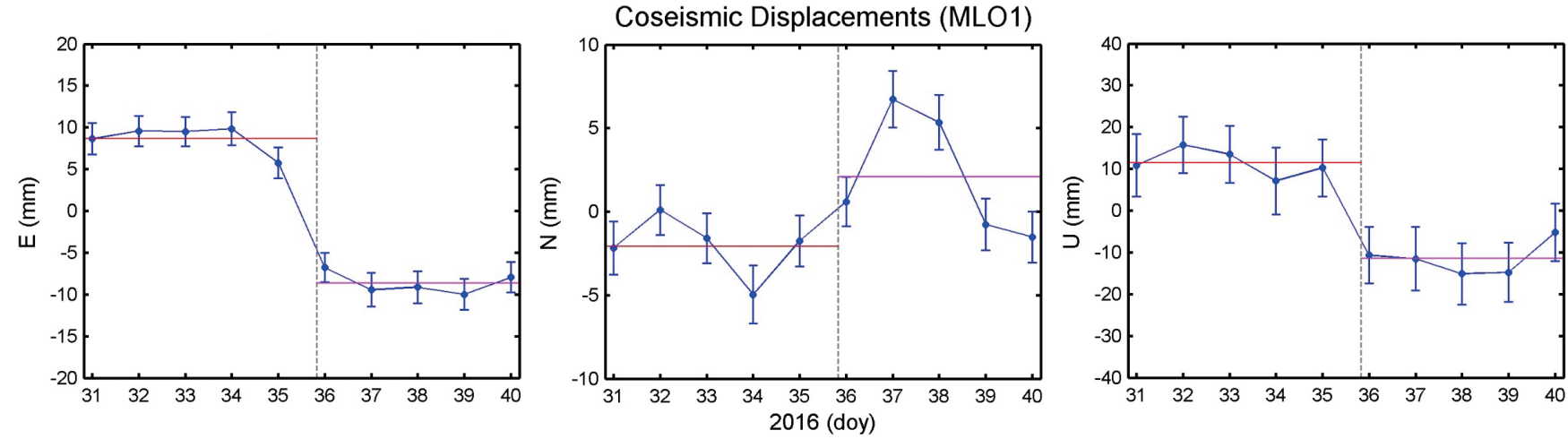

Fig. 11. Calculation of coseismic displaces by GPS time series of MLO1 station in east, north and up components, respectively. Blue dot with error bar indicates the daily solution. Gray dashed line shows occurrence time of the Meinong earthquake. Red and pink lines indicate mean value of 5-days daily solution before and after Meinong earthquake. (Color online only)

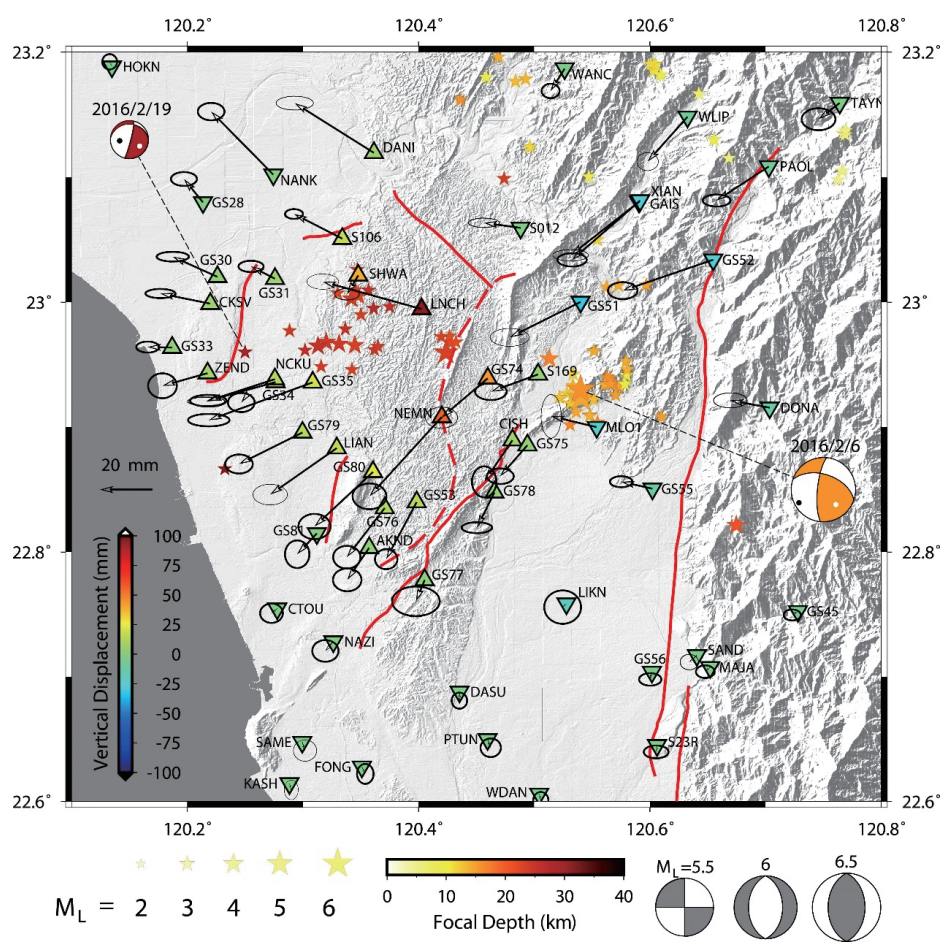

Fig. 12. Horizontal and vertical coseismic deformation of the Meinong earthquake. Black arrows represent the horizontal coseismic displacements with $95 \%$ confidence error ellipse shown at the tip of each displacement vector. Triangles with color-coded scale represent the vertical coseismic displacements, where triangles and inverse triangles indicate coseismic uplift or subsidence, respectively. Stars color-coded with focal depth indicate the main shock and aftershocks of Meinong earthquake. (Color online only) 
horizontal and vertical components. The maximum horizontal coseismic displacements is about $50 \mathrm{~mm}$ at NEMN station and $100 \mathrm{~mm}$ at $\mathrm{LNCH}$ station for vertical component (Table 3). If WNW-ESE trending nodal plane with dipping to north is taken as the fault plane, the focal mechanism of Meinong earthquake is a left-lateral strike-slip event with thrust component, thus the major coseismic displacements moved southwestward. However, the nearly E-W trending or NW-SE trending coseismic displacements were observed, especially close to Tainan area. It is surprisingly, the nearfield coseismic displacements are in general smaller than those of far-field, horizontal displacements up to about 40 $50 \mathrm{~mm}$ at the far field of SW and NE direction of epicenter.

\section{DISCUSSION}

\subsection{Reassessment of Seismic Hazards of High Strain Rate in SW Taiwan}

In general, the velocity vector directions are more or less perpendicular to the major active structures of the foldand-belt (Fig. 7a) with high strain accumulation (Fig. 8). The background seismic activities and historical large earthquakes also point out the high seismogenic potential in Chiayi-Tainan area (Fig. 2). Also, Tsai et al. (2012) did the crustal deformation modeling by GPS data from 1993 - 2007, the results suggest that the frontal thrust fault system in the Chiayi-Tainan area has a high potential for large earthquakes. In addition, the velocities increase southward with significant counterclockwise rotation of velocity vectors in the coastal area of Kaohsiung-Pingtung, which was related to tectonic extrusion (Lu and Malavieille 1994; Hu et al. 1997, 2001; Lacombe et al. 2001; Malavieille et al. 2002; Tsai 2013; Tsai et al. 2015). In previous study of block mode (Ching et al. 2011), only Chihshang and Chaochu faults were taken account as major strike-slip faults responsible for tectonic extrusion, however, the result of shear strain (Fig. 8b) suggest that the right-lateral shear is dominant north of the Chihshan fault, this observation is consistent with discontinuous and distributed surface lineaments from geomorphological analysis (Shyu et al. 2005). Thus we suggest that these right-lateral fault systems responsible for tectonic extrusion could be act as the potential seismogenic faults in SW Taiwan. In addition, both principal and shear strain rates also increase in this area, however the background seismicity is low in comparison with Chiayi-Tainan area. For instance, the PlioPleistocene Gutingkeng Formation could play an important role in high strain accumulation because it consists of very thick mudstone, which is relative softer in comparison with other geological formations in this region. The widespread soft mudstone could result in plastic deformation and form rapid deformation and release energy by creeping behavior of the décollement. Based on 531 GPS observations during 1995 - 2005, Ching et al. (2011) used block model to calculate the slip rate deficit and interseismic slip rate of 21 faults in Taiwan. They suggested that high slip rate deficits predicted in southwestern Taiwan. For example, they suggested slip rate deficits in Tainan fault and Meilin fault were 18.8 and $33.9 \mathrm{~mm} \mathrm{yr}^{-1}$, respectively. These high slip rate deficits are unrealistic because the aseismic creeping should contribute a significant amount of surface deformation in fold-and-thrust belt with weak décollement and mudstone of the Gutingkeng Formation. In addition, distributed fault-related folds could also accommodate the surface deformation. Thus the assessment of seismic hazards will be overestimated in terms of slip rate deficits predicted by block models.

\subsection{Triggered Slip from Shallow Structures from Meinong Earthquake}

Even part of the high strain rate could be attributed by aseismic deformation and fault-related folding in SW Taiwan, the mid-crust level under the major décollement could be a seimogenic region. The Meinong Earthquake occurred in a region of low background seismicity (Fig. 2) with mid-crust level focal depth which reflects the seismogenic fault could locate in deep depth. The vertical coseismic deformation of Meinong earthquake show the maximum uplift is about $100 \mathrm{~mm}$ at station LNCH (Longchi Station, Fig. 12) located west of Lungchuan Fault (Fig. 3), and vertical displacement is about 2 times higher than the horizontal displacement (about $50 \mathrm{~mm}$ ). It is worthy to note that no significant velocity discontinuity of the LNCH station with the nearby cGPS stations (ex. SHWA station, Fig. 7) according to the interseismic velocity field from 2007 - 2015 in this study. The interseismic horizontal velocities of $\mathrm{LNCH}$ and SHWA stations are about 25.3 and $21.3 \mathrm{~mm} \mathrm{yr}^{-1}$ with the direction about 252 and $259^{\circ}$, respectively. About the vertical component, the LNCH and SHWA stations are 9.1 and $5.7 \mathrm{~mm} \mathrm{yr}^{-1}$ uplift. However, the behavior of coseismic deformation of those two stations is very different. The coseismic uplift of SHWA only about $38 \mathrm{~mm}$, thus the LNCH is almost 2.5 times larger than that of SHWA. Furthermore, the horizontal coseismic displacements are also large differences between SHWA and LNCH stations. Huang et al. (2016b) used seismic, cGPS and InSAR data to do the joint inversion of source parameters of the Meinong Earthquake, the result suggested that the single fault plane connected with deep décollement poorly fit the anomalous coseismic uplift adjacent to west of the Lungchuan fault. The optimal model suggested that the coseismic slips should be triggered by shallower décollement about $5-10 \mathrm{~km}$ depth, in which the ramp duplex control the deformation of Lungchung fault and the adjacent fault-related folding. The coseismic horizontal deformation (Fig. 12) in this study shows that several stations parallel to the CSF all move toward to southwest, only some stations near Longchi or across the HCLF and Tainan Tableland showed the displacements toward to the west. Some stations near to the epicenter show 
less coseismic displacements (ex. stations: S169, MOL1; Fig. 12)than that of far filed stations. It also implies that the horizontal displacement is mainly controlled by the foldand-thrust system connected with N-S trending shallow décollement (Le Béon et al. 2017). This triggering of coseismic slip from the shallow structure was also highlighted by Lin et al. (2016) in 2010 Jiashian earthquake. It implies that the moderate earthquakes such as the Jiashian and Meinong events could trigger multiple fault segments and fault-related-folding above the weak shallow décollement.

\subsection{Pre-Seismic Baseline Variation of cGPS}

The precursory strain rate change around the source regions might attribute to pre-seismic slip in the surrounding regions of the fault segments that will break. The transient pre-seismic slip has been hypothesized for geological faults in laboratory rock experiments in terms of rock friction (Dieterich 1979). Roeloffs (2006) has reported best documented examples of deformation rate changes prior to earthquake, such as the $1944 \mathrm{M}_{\mathrm{s}}$ 8.2 Tonankai earthquake (Sagiya 1998; Linde and Sacks 2002), $1946 \mathrm{M}_{\mathrm{w}} 8.3$ Nankaido earthquake (Sato 1982; Linde and Sacks 2002), 1978 M 7.0 Izu-Oshima-Kinkai earthquake (Inouchi and Sato 1979; Wakita 1981), $2001 \mathrm{M}_{\mathrm{w}}$ 7.6 Peru earthquake (Melbourne and Webb 2002). In Taiwan, a decrease of creeping rate across the Chihshang fault before the $2003 \mathrm{M}_{\mathrm{w}} 6.8$ Chengkung earthquake was observed from creep-meters array (Jian-Cheng Lee, personal communication). A significant increase in soil-gas concentrations was recorded 2 months before the $2013 \mathrm{M}_{\mathrm{L}} 6.4$ Rueisuei earthquake in eastern Taiwan (Fu et al. 2016). A significant increase of soil radon concentrations

Table 3. Coseismic displacement of the Meinong Earthquake. CosE, CosN, CosU represent the E-W, N-S and vertical displacements, respectively.

\begin{tabular}{|c|c|c|c|c|c|c|c|c|c|c|c|}
\hline Site & Lon. $\left({ }^{\circ}\right)$ & ) & $\operatorname{Cos} \mathrm{E}(\mathrm{mm})$ & $\operatorname{CosN}(\mathbf{m m})$ & $\operatorname{Cos} \mathrm{U}(\mathbf{m m})$ & Site & Lon. $\left({ }^{\circ}\right)$ & Lat. $\left(^{\circ}\right)$ & osE (mm) & $\operatorname{CosN}(\mathbf{m m})$ & $\operatorname{Cos} \mathrm{U}(\mathrm{mm})$ \\
\hline AKND & 120.35726 & 22.80331 & $3.3 \pm 2.2$ & $-122+18$ & $3.0 \pm 3.0$ & GS81 & 120.31207 & 22.81486 & 1.9 & $-7.9 \pm 2.2$ & $-0.5 \pm 2.9$ \\
\hline $\mathrm{CISH}$ & 123 & 22.8 & $-10.8 \pm 1.9$ & $-15.8 \pm 2.4$ & $8.2 \pm$ & HOKN & 120.13488 & 23.18838 & $-0.9 \pm 1.2$ & 2 & \pm 2.8 \\
\hline CKSV & 120.22000 & 22.99885 & $-19.0 \pm 2.3$ & $3.9 \pm 0.7$ & $7.3 \pm 5.3$ & KASH & 120.28835 & 22.61449 & $0.7 \pm 1.1$ & $-2.5 \pm 1.5$ & $-1.5 \pm 3.2$ \\
\hline CTOU & 120.27784 & 22.75468 & $-2.2 \pm 1.8$ & $-1.8 \pm 1.5$ & $0.0 \pm 3.1$ & LIAN & 120.32923 & 22.88328 & $-25.3 \pm 2.7$ & $-17.7 \pm 1.6$ & $15.8 \pm 3.4$ \\
\hline DANI & 120.36139 & 23.11945 & $-30.1 \pm 2.9$ & $18.9 \pm 1.1$ & $7.7 \pm 3.3$ & LIKN & 120.52790 & 22.75861 & $-1.5 \pm 2.9$ & $-1.3 \pm 2.6$ & $-19.4 \pm 14.0$ \\
\hline DASU & 120.43542 & 22.68794 & $-0.1 \pm 1.2$ & $-3.4 \pm 1.2$ & $-1.9 \pm 2.5$ & $\mathrm{LNCH}$ & 120.40261 & 22.99458 & $-37.6 \pm 2.5$ & $10.4 \pm 1.2$ & $95.4 \pm 7.8$ \\
\hline DONA & 120.70351 & 22.91562 & $-15.0 \pm 2.6$ & $2.8 \pm 1.2$ & $-12.6 \pm 3.2$ & MAJA & 120.65205 & 22.70764 & $-1.9 \pm 1.5$ & $-1.7 \pm 1.0$ & $-1.4 \pm 3.4$ \\
\hline FONG & 120.35106 & 22.62775 & $1.3 \pm 1.3$ & $-2.7 \pm 1.6$ & $-3.2 \pm 2.9$ & MLO1 & 120.55400 & 22.90000 & $-17.3 \pm 1.6$ & $4.1 \pm$ & $-23.0 \pm 3.8$ \\
\hline GAIS & 120.59062 & 23.08029 & $-26.0 \pm 2.8$ & $-20.3 \pm 0.9$ & $-21.1 \pm 3.5$ & NANK & 120.27439 & 23.10199 & $-23.6 \pm 2.1$ & $24.0 \pm 1.4$ & $-0.8 \pm 5.9$ \\
\hline GS28 & 120.21358 & 23.07986 & $-7.2 \pm 2.0$ & $8.9 \pm 1.1$ & $-0.6 \pm 6.4$ & NAZI & 120.32633 & 22.72824 & $-3.0 \pm 2.0$ & $-3.6 \pm 1.7$ & $-0.9 \pm 4.6$ \\
\hline GS30 & 120.22612 & 23.02032 & $-17.0 \pm 2.5$ & $7.7 \pm 0.8$ & $3.5 \pm 5.0$ & NCKU & 120.27581 & 22.93845 & $-26.1 \pm 2.9$ & $-8.5 \pm 0.7$ & $13.7 \pm 5.7$ \\
\hline GS31 & 12 & 5 & -9 . & & & $\mathrm{N}$ & 8 & 2 & $.5 \pm 2.6$ & & 6 \\
\hline GS33 & 120.18695 & 22.96369 & $-9.3 \pm 1.8$ & $0.2 \pm 0.9$ & $3.4 \pm 4.0$ & PAOL & 120.70287 & 23.10862 & $-19.9 \pm 2.2$ & $-13.0 \pm 0.9$ & $-8.0 \pm 2.7$ \\
\hline GS34 & 12 & 2 & $-25.6 \pm 2.8$ & & 10 & N & 68 & 5 & $1.2 \pm 1.6$ & $-3.2=$ & 9 \\
\hline GS35 & 120.30849 & 22.93581 & $-39.5 \pm 3.2$ & $-14.3 \pm 1.0$ & $20.9 \pm 5.1$ & S012 & 120.48826 & 23.05947 & $-14.0 \pm 2.4$ & $1.9 \pm 0.7$ & $-1.3 \pm 4.7$ \\
\hline GS45 & 120.72800 & 22.75250 & $-2.2 \pm 1.3$ & $-1.4 \pm 0.9$ & $-4.0 \pm 4.4$ & SI & 120.33409 & 23.05079 & $-18.4 \pm 1.4$ & $9.4 \pm 0.0$ & $16.4 \pm 5.7$ \\
\hline GS51 & 120.54006 & 23.00022 & $-27.0 \pm 3.0$ & $-13.5 \pm 1.4$ & $-31.4 \pm 3.6$ & S169 & 120.50331 & 22.94229 & $-17.9 \pm 2.5$ & $-6.6 \pm 1.3$ & $4.4 \pm 3.5$ \\
\hline GS52 & 120.65472 & 23.03402 & $-34.4 \pm 2.3$ & $-11.8 \pm 1.3$ & $-25.4 \pm 3.0$ & S23R & 120.60617 & 22.64498 & $-0.3 \pm 1.9$ & $-2.5 \pm 1.0$ & $-1.3 \pm 4.2$ \\
\hline GS53 & 120.39831 & 22.83998 & $-11.6 \pm 1.7$ & $-21.7 \pm 1.6$ & $14.5 \pm 3.3$ & SAME & 120.29946 & 22.64763 & $1.0 \pm 1.8$ & $-3.2 \pm 1.7$ & $-2.0 \pm 2.7$ \\
\hline GS55 & 120.60224 & 22.85069 & $-11.9 \pm 1.7$ & $2.7 \pm 0.9$ & $-10.2 \pm 4.1$ & SAND & 120.64064 & 22.71727 & $-2.9 \pm 1.4$ & $-2.6 \pm 1.2$ & $-3.0 \pm 4.9$ \\
\hline GS56 & 120.60173 & 22.70388 & $-0.6 \pm 1.7$ & $-2.8 \pm 1.0$ & $-3.4 \pm 3.4$ & HWA & 120.34781 & 23.02143 & $-4.3 \pm 1.9$ & $-7.2 \pm 0.9$ & $38.3 \pm 5.5$ \\
\hline GS74 & 120.45980 & 22.93916 & $-17.6 \pm 2.5$ & $-15.0 \pm 1.6$ & $43.9 \pm 5.1$ & TAYN & 120.76419 & 23.15934 & $-8.1 \pm 2.6$ & $-6.2 \pm 1.7$ & $-1.8 \pm 3.1$ \\
\hline GS75 & 120.49412 & 22.88556 & $-10.3 \pm 2.1$ & $-11.8 \pm 1.2$ & $4.2 \pm 3.3$ & WANC & 120.52633 & 23.18684 & $-5.4 \pm 1.4$ & $-8.5 \pm 1.1$ & $-3.1 \pm 3.9$ \\
\hline GS76 & 120.37070 & 22.83527 & $-14.4 \pm 2.1$ & $-18.7 \pm 1.8$ & $12.3 \pm 5.2$ & WDAN & 120.50431 & 22.60606 & $0.6 \pm 1.2$ & $-2.4 \pm 1.3$ & $-3.1 \pm 2.5$ \\
\hline GS77 & 120.40526 & 22.77756 & $-3.3 \pm 3.7$ & $-8.1 \pm 2.3$ & $3.9 \pm 5.2$ & WLIP & 120.63256 & 23.14829 & $-15.2 \pm 1.7$ & $-17.1 \pm 1.4$ & $-7.5 \pm 3.3$ \\
\hline GS78 & 120.46561 & 22.84779 & $-6.7 \pm 2.4$ & $-13.4 \pm 0.9$ & $5.0 \pm 3.1$ & XIAN & 120.59155 & 23.08139 & $-25.9 \pm 2.3$ & $-22.6 \pm 1.0$ & $-26.1 \pm 2.4$ \\
\hline GS79 & 120.29961 & 22.89573 & $-24.1 \pm 2.1$ & $-12.0 \pm 1.5$ & $14.8 \pm 4.6$ & ZEND & 120.21756 & 22.94327 & $-17.2 \pm 2.2$ & $-4.8 \pm 1.9$ & $9.5 \pm 4.3$ \\
\hline GS80 & 120.36064 & 22.86419 & $-22.3 \pm 2.5$ & $-20.8 \pm 2.0$ & $22.9 \pm 5.3$ & & & & & & \\
\hline
\end{tabular}


was also observed at several stations about two weeks before the Meinong earthquake in southern Taiwan (Fu et al. 2017). From the high precision of continuous GPS data, an appreciable decrease in extension rate was also detected approximately 4 months before the Rueisuei earthquake (Fu et al. 2016).

The hypothesis of strain change prior to Meinong earthquakes in terms of cGPS baseline variation is similar to extension rate change prior to the 2013 Rueisuei event. The baselines of two cGPSs chosen are located within the earthquake preparation zones and strain radius (Dobrovolsky et al. 1979). We analyze 26 baselines in Kaohsiung-Pingtung area (Fig. 9) to characterize the pre-seismic baseline variation of the Meinong earthquake. The anomaly of baseline variation of 8 baselines was observed in Kaohsiung-Pingtung area before the Meinong earthquake (Fig. 9). In addition, most anomalies of baseline variation are located in the area between the ZCF, HSF, HCLF and CSF (Fig. 3) or near the area of epicenter. These baselines are AKND-CTOU, DONAMOL1, DONA-S169, LIKN-AKND, MOLI-S169, NCKUZEND, S106-NANK, and SHWA-S106 (Fig. 9). Figure 13 presents the time series of 8 baseline variations from 2007 to June 2016. The blue and red dots with light gray bar indicate the baseline change of east and north components, baseline length variation and uncertainties of two relative site, respectively. The vertical gray dash line indicates the earthquake events which were auto picked and plotted by certain constraints (distance from GPS stations $=25 \mathrm{~km}, \mathrm{M}_{\mathrm{L}}>5.0$, depth $<25 \mathrm{~km}$ ). The green line is mean value calculate by moving average method (moving time window $=10$ days, shifting interval $=1$ day). It is worthy to note that the velocities of baseline length variation in Fig. 13 are slight different from the result demonstrated in Fig. 9. In this session we want to discuss the anomalous phenomenon of time series in baseline length, thus we use data extend to June 2016. We also use the pink and light-blue arrows to mark the shortening and extension of baseline length variation, respectively. The light-yellow and green patches demonstrated the time period with baseline length variation is close to zero and the postseismic change of Jiashian earthquake (4 March 2010, Fig. 10). The time period of postseismic change time relies on the parameter $\tau_{j}$ which is estimated by time series analysis (Tsai et al. 2015).

Only two baseline AKND-CTOU (Fig. 13h) and DONAMOL1 (Fig. 13c) demonstrate small extension with a rate of 1.6 and $1.9 \mathrm{~mm} \mathrm{yr}^{-1}$. The extension of baseline AKND-CTOU may be caused by the tectonic escape, but the DONA-MOL1 could be from the simple linear regression without correction of the coseismic offset resulted from Jiashian earthquake. When we estimated the rate change, the most time series of DONA-MOL1 demonstrate the shortening behaviors. The other 6 baselines all demonstrated the shortening behavior

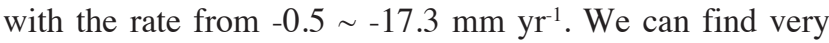
clear anomalous phenomenon in time series of those 8 baseline length variations which is the shortening or extension rate will be slowed down and close to zero before Meinong earthquake. The duration of the anomalies are about 9 months to 2 year, depends on the location of baselines. The MLO1S169, DONA-S169, and DONA-MLO1 are 3 baselines located near the epicenter area, the duration of the anomalies is about 9,12 , and 13 months, respectively (Figs. 13a - c). Furthermore, these 3 baselines and baseline SHWA-S106 are also effected by the 2010 Jiashian Earthquake, in which the similar "rate-slow-down" anomalies are also shown in the time series before the Jiashian Earthquake. It is worthy to note that the rate did not decay to zero along baseline SHWA-S106, it did slow down before the Jiashian event (Fig. 13d). The duration of the bassline anomalies of Meinong earthquake of LIKN-AKND, AKND-CTOU, NCKUZEND, S106-NANK, and SHWA-S106 (Figs. 13d - h) are about 14, 16, 20, 22, and 24 months. Obviously, the duration time of anomalies is correlated to the distances of baseline location and epicenter. The more far away from the epicenter, the longer anomalies duration (the location of those baseline can see Fig. 13). Based on dilatancy-diffusion model, Scholz et al. (1973) suggested that the pre-slip strain anomaly and could be observed on three major stages: elastic strain buildup (stage I), dilatancy dominant (stage II), and influx water dominant (stage III). Seismic slip may nucleate on fault patches due to the frictional drops with increasing slip or sliding speed (Dieterich 1992; Ohnaka 1992), an earthquake may occur on along-strike or down-dip extension while aseismic deformation rates accelerate. However, according to dilatancy-diffusion model (Scholz et al. 1973), the observed anomalies of baseline length rate variation seem to be "slow-down" and resulted from the closure of preexisting cracks before the nucleation of Meinong earthquake.

\section{CONCLUSION}

In this study we characterize the high strain accumulation across the fold-and-thrust belt in SW Taiwan based on the Continuous GPS from 2007 - 2015. In general, both principal and shear strain rate consistently reflect the accommodation of the major active structures in fold-andthrust belt of western Foothills. In addition, the distributed right-lateral shear zone west of the Chishan fault and faultrelated folding and aseismic creeping across the Lungchuan fault are also largely accommodate the deformation in study area. In addition, the mechanical heterogeneity of mudstone in the Gutingkeng formation might play a crucial role for aseismic creeping. For assessment of seismic hazard in SW Taiwan, the previous block model based on GPS measurement suggested a high seismic risk in SW Taiwan without taking these deformation into account should overestimate the seismic hazards in SW Taiwan. Based on distribution of coseismic uplift across the Lungchuan fault to the Tainan tableland, the multiple fault slips along a shallow structures were triggered by the $2016 \mathrm{M}_{\mathrm{w}}$ Meinong earthquake at about 
(a)

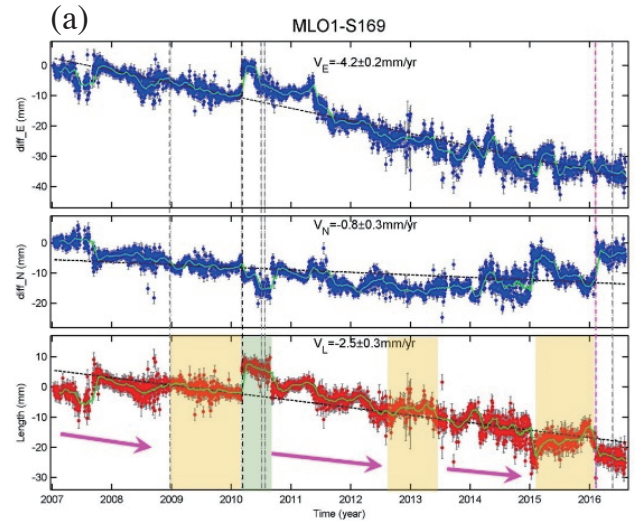

(c)

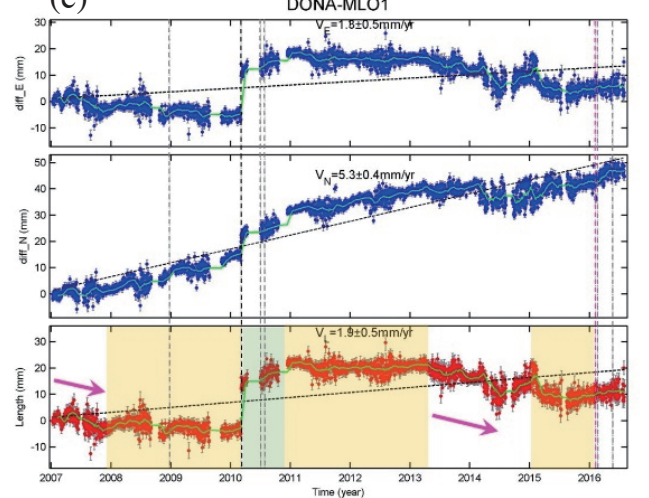

(e)

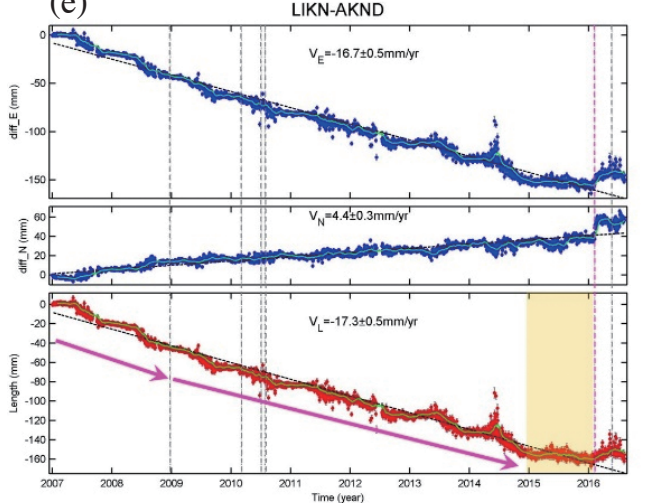

(g)
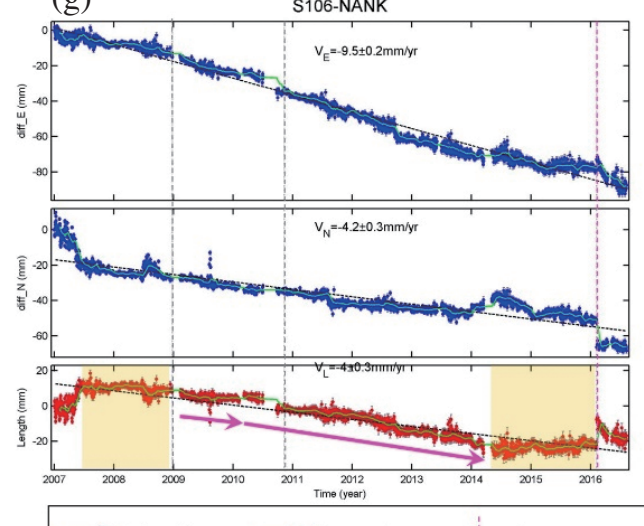
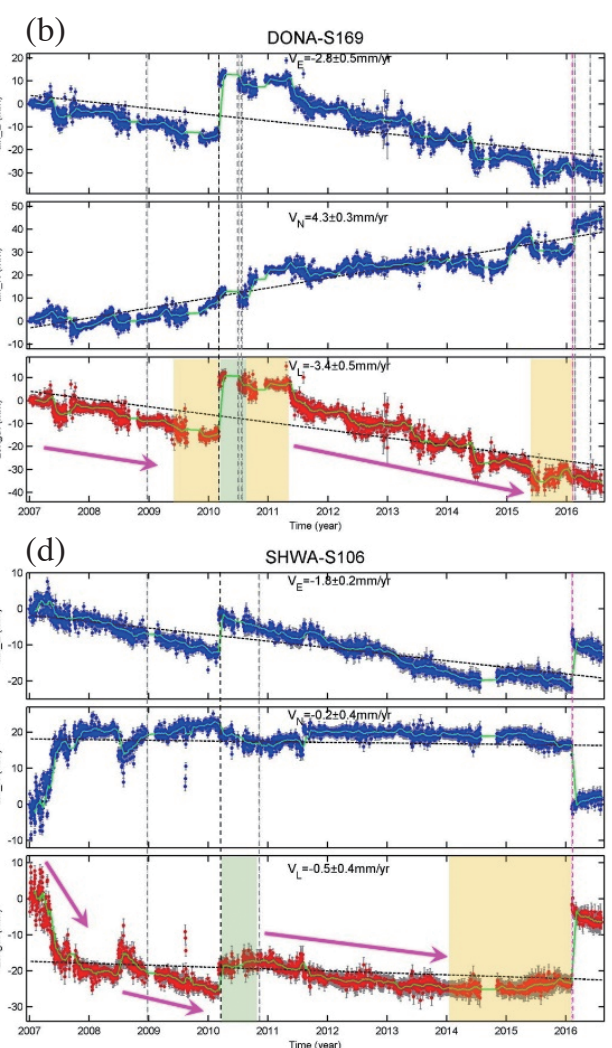

(f)

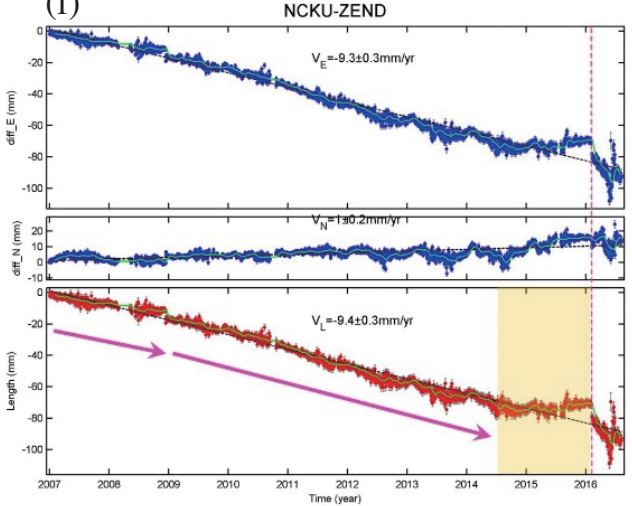

(h)

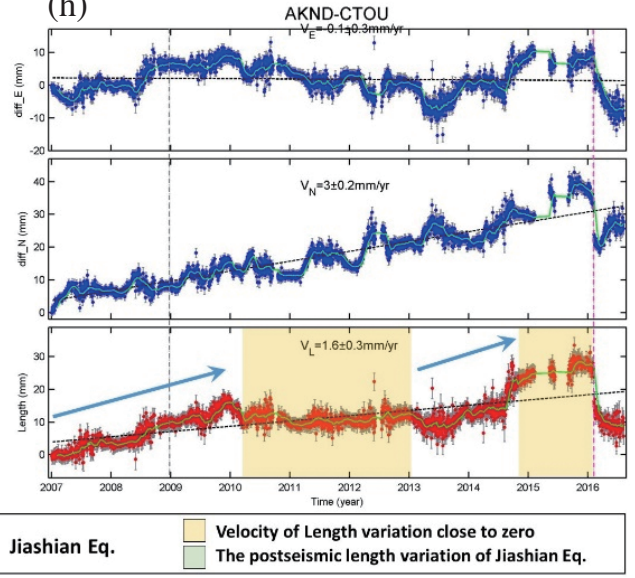

Fig. 13. Time series of 8 baseline change. Blue, red dots and gray bars indicate the baseline of east and north components, baseline length variation, and uncertainties of two relative sites, respectively. Vertical gray dashed lines indicate the different earthquake events. Green line is mean value of baseline calculated by moving average method. (Color online only) 
$14.6 \mathrm{~km}$. The surface coseismic deformation is mainly controlled by a fault-related folding structures connected to the shallow décollement around $5-10 \mathrm{~km}$ depth, in which the moderate earthquakes locate in mid-crust could trigger slip along the weak décollement. The pre-seismic baseline variation of cGPS is observed in 8 baselines near the epicenter of the Meinong earthquake. The rate-slow-down anomalies could be considered as the possible precursor of the Meinong earthquake.

Acknowledgements The comments and suggestions from four anonymous reviewers and Guest Editor Ruey-Juin Rau are deeply appreciated. We are grateful to many colleagues at the Seismological Center, Central Weather Bureau, Central Geological Survey and Institute of Earth Sciences, Academia Sinica who have participated in maintaining continuous GPS array and data processing operations. We are indebted to the Institute of Earth Sciences, Academia Sinica (IESAS), Central Geological Survey (CGS), Ministry of the Interior (MOI), The Geospatial Information Authority of Japan (GSI), Water Resources Agency, Ministry of Economic Affairs (WRA), Taiwan Earthquake Center (TEC), and other Agency of Taiwan as well as the International GNSS Service (IGS) community for providing the continuous GPS data used in this study. Generic Mapping Tools software (Wessel et al. 2013) is used to plot the data. This study was financially supported by the Central Weather Bureau and Ministry of Science and Technology of Taiwan under grant MOST 105-2116-M-052-003.

\section{REFERENCES}

Altamimi, Z., P. Sillard, and C. Boucher, 2002: ITRF2000: A new release of the International Terrestrial Reference Frame for earth science applications. J. Geophys. Res., 107, ETG2-1-ETG2-19, doi: 10.1029/2001JB000561. [Link]

Angelier, J., 1986: Preface to the special issue on "Geodynamics of the Eurasian-Philippine Sea Plate Boundary". Tectonophysics, 125, IX-X, doi: 10.1016/00401951(86)90003-X. [Link]

Angelier, J., J. C. Lee, H. T. Chu, C. Y. Lu, M. Fournier, J. C. Hu, N. T. Lin, B. Deffontaines, B. Delcaillau, O. Lacombe, and T. Q. Lee, 1995: Crustal extension in an active orogen: Taiwan. In: Tsien, H. H. (Ed.), ACT Int. Conf., Extended. Abstr. Geol. Soc. China Spec. Publ., Taipei City, Taiwan, 25-32.

Bock, Y., 1994: Crustal deformation and earthquakes. Geotimes, 39, 16-18.

Bock, Y. and D. Melgar, 2016: Physical applications of GPS geodesy: A review. Rep. Progr. Phys., 79, doi: 10.1088/0034-4885/79/10/106801. [Link]

Bock, Y., S. Wdowinski, P. Fang, J. Zhang, S. Williams, H. Johnson, J. Behr, J. Genrich, J. Dean, and M. Van
Domselaar, 1997: Southern California permanent GPS geodetic array: Continuous measurements of regional crustal deformation between the 1992 Landers and 1994 Northridge earthquakes. J. Geophys. Res., 102, 18013-18033, doi: 10.1029/97JB01379. [Link]

Bos, A. G., W. Spakman, and M. C. J. Nyst, 2003: Surface deformation and tectonic setting of Taiwan inferred from a GPS velocity field. J. Geophys. Res., 108, 2458, doi: 10.1029/2002JB002336. [Link]

Bürgmann, R. and W. Thatcher, 2013: Space geodesy: A revolution in crustal deformation measurements of tectonic processes. Geol. Soc. Amer. Spec. Papers, 500, 397-430, doi: 10.1130/2013.2500(12). [Link]

Chang, C. P., T. Y. Chang, J. Angelier, H. Kao, J. C. Lee, and S. B. Yu, 2003: Strain and stress field in Taiwan oblique convergent system: Constraints from GPS observation and tectonic data. Earth Planet. Sci. Lett., 214, 115-127, doi: 10.1016/S0012-821X(03)00360-1. [Link]

Chang, L. S., M. Chow, and P. Y. Chen, 1947: The Taiwan earthquake of December 5, 1946. Taiwan Geol. Surv. Bull., 1, 17-20.

Ching, K. E., R. J. Rau, J. C. Lee, and J. C. Hu, 2007: Contemporary deformation of tectonic escape in SW Taiwan from GPS observations, 1995-2005. Earth Planet. Sci. Lett., 262, 601-619, doi: 10.1016/j.eps1.2007.08.017. [Link]

Ching, K. E., R. J. Rau, K. M. Johnson, J. C. Lee, and J. C. $\mathrm{Hu}, 2011$ : Present-day kinematics of active mountain building in Taiwan from GPS observations during 1995-2005. J. Geophys. Res., 116, B09405, doi: 10.1029/2010JB008058. [Link]

Crespi, J. M., Y. C. Chan, and M. S. Swaim, 1996: Synorogenic extension and exhumation of the Taiwan hinterland. Geology, 3, 247-250, doi: 10.1130/0091-7613(19 96)024<0247:SEAEOT>2.3.CO;2. [Link $]$

Deffontaines, B., O. Lacombe, J. Angelier, F. Mouthereau, C. T. Lee, J. Deramond, J. F. Lee, M. S. Yu, and P. M. Pin, 1997: Quaternary transfer faulting in Taiwan Foothills: Evidence from a multisource approach. Tectonophysics, 274, 61-82, doi: 10.1016/S00401951(96)00298-3. [Link]

Dieterich, J. A., 1992: Earthquake nucleation on faults with rate- and state-dependent strength. Tectonophysics, 211, 115-34, doi: 10.1016/0040-1951(92)90055-B. [Link]

Dieterich, J. H., 1979: Modeling of rock friction: 2. Simulation of preseismic slip. J. Geophys. Res., 84, 21692175, doi: 10.1029/JB084iB05p02169. [Link]

Dixon, T. H., 1991: An introduction to the Global Position System and some geological applications. Rev. Geophysics, 29, 249-276, doi: 10.1029/91RG00152. [Link]

Dobrovolsky, I. P., S. I. Zubkov, and V. I. Miachkin, 1979: 
Estimation of the size of earthquake preparation zone. Pure Appl. Geophys., 117, 1025-1044, doi: 10.1007/ BF00876083. [Link]

Dong, D., P. Fang, Y. Bock, M. K. Cheng, and S. Miyazaki, 2002: Anatomy of apparent seasonal variations from GPS-derived site position time series. J. Geophys. Res., 107, ETG9-1-ETG9-16, doi: 10.1029/2001JB000573. [Link]

Fruneau, B., E. Pathier, D. Raymond, B. Deffontaines, C. T. Lee, H. T. Wang, J. Angelier, J. P. Rudant, and C. P. Chang, 2001: Uplift of Tainan Tableland (SW Taiwan) revealed by SAR interferometry. Geophys. Res. Lett., 28, 3071-3074, doi: 10.1029/2000GL012437. [Link]

Fu, C.-C., T. F. Yang, M. C. Tsai, L. C. Lee, T. K. Liu, V. Walia, C. H. Chen, W. Y. Chang, A. Kumar, and T. H. Lai, 2016: Exploring the relationship between soil degassing and seismic activity by continuous radon monitoring in the Longitudinal Valley of eastern Taiwan. Chem. Geol., CHEMGE-18212, 1-13, doi: 10.1016/j. chemgeo.2016.12.042. [Link]

Fu, C.-C., V. Walia, T. F. Yang, L.-C. Lee, T.-K. Liu, C.-H. Chen, A. Kumar, S.-J. Lin, T.-H. Lai, and K.-L. Wen, 2017: Preseismic anomalies in soil-gas radon associated with 2016 M 6.6 Meinong earthquake, Southern Taiwan. Terr. Atmos. Ocean. Sci., 28, 787-798, doi: 10.3319/TAO.2017.03.22.01. [Link]

Hager, B. H., R. W. King, and M. H. Murray, 1991: Measurement of crustal deformation using the Global Position System. Annu.Rev. Earth Planet. Sci., 19, 351-382, doi: 10.1146/annurev.ea.19.050191.002031. [Link]

Herring, T. A., R. W. King, and S. C. McClusky, 2010: GLOBK Reference Manual (Global Kalman Filter VLBI and GPS Analysis) Release 10.4. MIT Department of Earth, Atmospheric, and Planetary Sciences. Massachusetts Institute of Technology, Cambridge, M.A., $91 \mathrm{pp}$.

Hickman, J. B., D. V. Wiltschko, J. H. Hung, P. Fang, and Y. Bock, 2002: Structure and evolution of the active fold-and-thrust belt of southwestern Taiwan from Global Positioning System analysis. In: Byrne, T. B. and C. S. Liu (Eds.), Geology and Geophysics of an Arc-Continent Collision, Taiwan, Geological Society of America Special Papers, Vol. 358, 75-92, doi: 10.1130/0-8137-2358-2.75. [Link]

Hou, C. S., J. C. Hu, L. C. Shen, J. S. Wang, C. L. Chen, T. C. Lai, C. Huang, Y. R. Yang, R. F. Chen, Y. G. Chen, and J. Angelier, 2005: Estimation of subsidence using GPS measurements, and related hazard: the Pingtung Plain, southwestern Taiwan. C. R. Geoscience, 337, 1184-1193, doi: 10.1016/j.crte.2005.05.012. [Link]

Hsieh, C. S., T. Y. Shih, J. C. Hu, H. Tung, M. H. Huang, and J. Angelier, 2011: Using differential SAR interferometry to map land subsidence: A case study in the Pingtung Plain of SW Taiwan. Nat.Hazards, 58, 1311-
1332, doi: 10.1007/s11069-011-9734-7. [Link]

Hsu, Y. J., M. Simons, S. B. Yu, L. C. Kuo, and H. Y. Chen, 2003: A two-dimensional dislocation model for interseismic deformation of the Taiwan mountain belt. Earth Planet. Sci. Lett., 211, 287-294, doi: 10.1016/ S0012-821X(03)00203-6. [Link]

Hsu, Y. J., S. B. Yu, M. Simons, L. C. Kuo, and H. Y. Chen, 2009: Inter-seismic crustal deformation in the Taiwan plate boundary zone revealed by GPS observations, seismicity, and earthquake focal mechanisms. Tectonophysics, 479, 4-18, doi: 10.1016/j.tecto.2008.11.016. [Link]

Hu, J. C. and J. Angelier, 2004: Stress permutations: 3-D distinct element analysis accounts for a common phenomenon in brittle tectonics. J. Geophys. Res., 109, B09403, doi: 10.1029/2003JB002616. [Link]

Hu, J. C., J. Angelier, and S. B. Yu, 1997: An interpretation of the active deformation of southern Taiwan based on numerical simulation and GPS studies. Tectonophysics, 274, 145-170, doi: 10.1016/S0040-1951(96)00302-2. [Link]

Hu, J. C., S. B. Yu, J. Angelier, and H. T. Chu, 2001: Active deformation of Taiwan from GPS measurements and numerical simulations. J. Geophys. Res., 106, 22652280, doi: 10.1029/2000JB900196. [Link]

Hu, J. C., C. S. Hou, L. C. Shen, Y. C. Chan, R. F. Chen, C. Huang, R. J. Rau, K. H. Chen, C. W. Lin, M. H. Huang, and P. F. Nien, 2007: Fault activity and lateral extrusion inferred from velocity field revealed by GPS measurements in the Pingtung area of southwestern Taiwan. J. Asian Earth Sci., 35, 287-302, doi: 10.1016/j. jseaes.2006.07.020. [Link]

Hu, J. C., M. H. Huang, H. Tung, C. Huang, Y. P. Kuo, and E. Tan, 2016: Reassessment of seismic hazards on high strain accumulation in SW Taiwan: Insight from multiple fault slip triggered by 2016 Meinong Earthquake. American Geophysical Union, Fall Meeting, San Francisco, Abstract, T23A-2887.

Huang, C. Y., W. Y. Wu, C. P. Chang, S. Tsao, P. B. Yuan, C. W. Lin, and K. Y. Lin, 1997: Tectonic evolution of accretionary prism in the arc-continent collision terrane of Taiwan. Tectonophysics, 281, 31-51, doi: 10.1016/ S0040-1951(97)00157-1. [Link]

Huang, M. H., J. C. Hu, C. S. Hsieh, K. E. Ching, R. J. Rau, and E. Pathier, 2006: A growing structure near the deformation front in SW Taiwan deduced from SAR interferometry and geodetic observation. Geophys. Res. Lett., 33, L12305, doi: 10.1029/2005GL025613. [Link]

Huang, M. H., J. C. Hu, K. E. Ching, R. J. Rau, C. S. Hsieh, E. Pathier, B. Fruneau, and B. Deffontaines, 2009: Active deformation of Tainan Tableland of southwestern Taiwan based on geodetic measurements and SAR interferometry. Tectonophysics, 466, 322-344, doi: 
10.1016/j.tecto.2007.11.020. [Link]

Huang, M. H., R. Bürgmann, and J. C. Hu, 2016a: Fifteen years of surface deformation in Western Taiwan: Insight from SAR interferometry. Tectonophysics, 692, 252-264, doi: 10.1016/j.tecto.2016.02.021. [Link]

Huang, M. H., H. Tung, E. J. Fielding, H. H. Huang, C. Liang, C. Huang, and J. C. Hu, 2016b: Multiple fault slip triggered above the $2016 \mathrm{Mw}$ 6.4 MeiNong earthquake in Taiwan. Geophys. Res. Lett., 43, 7459-7467, doi: 10.1002/2016GL069351. [Link]

Huang, S. T., K. M. Yang, J. H. Hung, J. C. Wu, H. H. Ting, W. W. Mei, and M. Lee, 2004: Deformation front development at the northeast margin of the Tainan basin, Tainan-Kaohsiung area, Taiwan. Mar. Geophys. Res., 25, 139-156, doi: 10.1007/s11001-005-0739-z. [Link]

Hudnut, K. W., 1995: Earthquake geodesy and hazard monitoring. Rev. Geophys., 33, 249-255, doi: 10.1029/95RG00406. [Link]

Inouchi, N. and H. Sato, 1979: Crustal deformation related to the Izu-Oshima Kinkai earthquake of 1978. Bull. Geograph. Surv. Inst., 23, 14-24.

Lacombe, O., F. Mouthereau, B. Deffontaines, J. Angelier, H. T. Chu, and C. T. Lee, 1999: Geometry and Quaternary kinematics of fold-and thrust units of southwestern Taiwan. Tectonics, 18, 1198-1223, doi: 10.1029/1999TC900036. [Link]

Lacombe, O.,F.Mouthereau,J.Anglier, and B. Deffontaines, 2001: Structure, geodetic and seismological evidence for tectonic escape in SW Taiwan. Tectonophysics, 333, 323-345, doi: 10.1016/S0040-1951(00)00281-X. [Link]

Lallemand, S. E. and H. H. Tsien, 1997: An introduction to active collision in Taiwan. Tectonophysics, 274, 1-4, doi: 10.1016/s0040-1951(96)00294-6. [Link]

Le Béon, M., M.-H. Huang, J. Suppe, S.-T. Huang, E. Pathier, W.-J. Huang, C.-L. Chen, B. Fruneau, S. Baize, K.-E. Ching, and J.-C. Hu, 2017: Shallow geological structures triggered during the $\mathrm{M}_{\mathrm{w}}$ 6.4 Meinong earthquake, southwestern Taiwan. Terr. Atmos. Ocean. Sci., 28, 663-681, doi: 10.3319/TAO.2017.03.20.02. [Link]

Leick, A., 1989: GPS Satellite Surveying, Wiley Interscience, New York, 352 pp.

Lin, A. T. and A. B. Watts, 2002: Origin of the West Taiwan basin by orogenic loading and flexure of a rifted continental margin. J. Geophys. Res., 107, doi: 10.1029/2001JB000669. [Link]

Lin, A. T., A. B. Watts, and S. P. Hesselbo, 2003: Cenozoic stratigraphy and subsidence history of the South China Sea margin in the Taiwan region. Basin Res., 15, 453478, doi: 10.1046/j.1365-2117.2003.00215.x. [Link]

Lin, C. W., S. T. Lu, and W. S. Chen, 2012: Active fault map of Taiwan: An explanatory text. Spec. Publ. Cent. Geol. Surv., 26, 1-30.

Lin, K. C., J. C. Hu, K. E. Ching, J. Angelier, R. J. Rau, S.
B. Yu, C. H. Tsai, T. C. Shin, and M. H. Huang, 2010: GPS crustal deformation, strain rate and seismic activity after the 1999 Chi-Chi earthquake in Taiwan. J. Geophys. Res., 115, B07404, doi: 10.1029/2009JB006417. [Link]

Lin, K. C., B. Delouis, J. C. Hu, J. M. Nocquet, and L. Mozziconacci, 2016: Reassessing the complexity of the rupture of the 2010 Jia-Shian Earthquake (Mw 6.2) in Southwestern Taiwan by inverting jointly teleseismic, strong-motion and CGPS data. Tectonophysics, 692, 278-294, doi: 10.1016/j.tecto.2015.09.015. [Link]

Linde, A. T. and I. S. Sacks, 2002: Slow earthquakes and great earthquakes along the Nankai Trough. Earth Planet. Sci. Lett., 203, 265-275, doi: 10.1016/S0012821X(02)00849-X. [Link]

Lu, C. Y. and J. Malavieille, 1994: Oblique convergence, indentation and rotation tectonics in Taiwan Mountain Belt: Insights from experimental modeling. Earth Planet. Sci. Lett., 121, 477-494, doi: 10.1016/0012-821X(94)90085-X. [Link]

Malavieille, J. and G. Trullenque, 2009: Consequences of continental subduction on forearc basin and accretionary wedge deformation in SE Taiwan: Insights from analogue modeling. Tectonophysics, 466, 377-394, doi: 10.1016/j.tecto.2007.11.016. [Link]

Malavieille, J., S. E. Lallemend, S. Dominquze, A. Deschamps, C. Y. Liu, C. S. Liu, and P. Schnurle, 2002: Arc-continent collision in Taiwan: New marine observations and tectonic evolution. In: Byrne, T. B. and C. S. Liu (Eds.), Geology and Geophysics of an Arc-Continent Collision, Taiwan, Geological Society of America Special Papers, Vol. 358, 187-211, doi: 10.1130/0-8137-2358-2.187. [Link]

Mao, A., C. G. A. Harrison, and T. H. Dixon, 1999: Noise in GPS coordinate time series. J. Geophys. Res., 104, 2797-2816, doi: 10.1029/1998JB900033. [Link]

Melbourne, T. I. and F. H. Webb, 2002: Precursory transient slip during the $2001 \mathrm{Mw}=8.4$ Peru earthquake sequence from continuous GPS. Geophys. Res. Lett., 29, doi: 10.1029/2002GL015533. [Link]

Mouthereau, F. and C. Petit, 2003: Rheology and strength of the Eurasian continental lithosphere in the foreland of the Taiwan collision belt: constraints from seismicity, flexure, and structural styles. J. Geophys. Res., 108, doi: 10.1029/2002JB002098. [Link]

Mouthereau, F., B. Deffontaines, O. Lacombe, and J. Angelier, 2002: Variation along the strike of the Taiwan thrust belt: Basement control on structural style, wedge geometry, and kinematics. Geol. Soc. Am., 358, 31-54, doi: 10.1130/0-8137-2358-2.31. [Link]

Nikolaidis, R., 2002: Observation of geodetic and seismic deformation with Global Positioning System. Ph.D. Thesis, University of California, San Diego, Dissertation Abstracts International, Vol. 65-09, 305 pp. 
Ohnaka, M., 1992: Earthquake source nucleation: A physical model for short-term precursors. Tectonophysics, 211, 149-178, doi: 10.1016/0040-1951(92)90057-D. [Link]

Roeloffs, E. A., 2006: Evidence for aseismic deformation rate changes prior to earthquakes. Annu. Rev. Earth Planet. Sci., 34, 591-627, doi: 10.1146/annurev. earth.34.031405.124947. [Link]

Sagiya, T., 1998: Crustal movements as earthquake precursors - leveling anomaly before the 1944 Tonankai earthquake revisited. Bull. Geogr. Surv. Inst., 44, 23-36.

Sagiya, T., S. Miyazaki, and T. Tada, 2000: Continuous GPS array and present-day crustal deformation of Japan. Pure Appl. Geophys., 157, 2303-2322, doi: 10.1007/ PL00022507. [Link]

Sato, H., 1982: On the changes in the sea level at Tosashimizu before the Nankaido earthquake of 1946. J. Seismol. Soc. Japan., 35, 623-626, doi: 10.4294/zi$\sin 1948.35 .4 \_623$. [Link]

Savage, J. C. and W. H. Prescott, 1973: Precision of geodolite distance measurements for determining fault movements. J. Geophys. Res., 78, 6001-6008, doi: 10.1029/ JB078i026p06001. [Link]

Scholz, C. H., L. R. Sykes, and Y. P. Aggarawal, 1973: Earthquakes prediction: A physical basis. Science, 181, 803-810, doi: 10.1126/science.181.4102.803. [Link]

Segall. P. and J. L. Davis, 1997: GPS applications for geodynamics and earthquake studies. Ann. Rev. Earth Planet. Sci., 25, 301-336, doi: 10.1146/annurev. earth.25.1.301. [Link]

Shen, Z. K., B. X. Ge, D. D. Jackson, D. Potter, M. Cline, and L. Y. Sung, 1996: Northridge earthquake rupture models based on the global positioning system measurements. Bull. Seism. Soc. Am., 86, S37-S48.

Shin, T. C., 1992: Some implications of Taiwan tectonic features from the data collected by the Central Weather Bureau Seismic Network. Meteorol. Bull., 38, 23-48. (in Chinese)

Shin, T. C., K. W. Kuo, P. L. Leu, C. H. Tsai, and J. S. Jiang, 2011: Continuous CWB GPS array in Taiwan and applications to monitoring seismic activity. Terr. Atmos. Ocean. Sci., 22, 521-533, doi: 10.3319/ TAO.2011.05.18.01(T). [Link]

Shyu, J. B. H., K. Sieh, Y. G. Chen, and C. S. Liu, 2005: Neotectonic architecture of Taiwan and its implications for future large earthquakes. J. Geophys. Res., 110, B08402, doi: 10.1029/2004JB003251. [Link]

Strang, G. and K. Borre, 1997: Linear Algebra, Geodesy, and GPS, Wellesley-Cambridge Press, $627 \mathrm{pp}$.

Sun, S. C., 1964: Photogeologica study of the Tainan-Kaohsiung Coastal plain area. Taiwan. Petrol. Geol. Taiwan, 3, 39-51.

Tabei, T. and W. L. Amin, 2002: Common-mode errors in the GPS coordinate time series - Application of spatial filtering technique. J. Geodetic. Soc., 48, 229-241.
Teng, L. S., 1990: Late Cenozoic arc-continent collision in Taiwan. Tectonophysics, 183, 57-76, doi: 10.1016/0040-1951(90)90188-E. [Link]

Tsai, M. C., 2013: Inter-seismic crustal deformation and seismic activity in southwestern Taiwan. Ph.D. Thesis, National Central University, Taoyuan City Taiwan, 250 pp. (in Chinese)

Tsai, M. C., S. B. Yu, Y. J. Hsu, H. Y. Chen, and H. W. Chen, 2012: Interseismic crustal deformation of frontal thrust fault system in the Chiayi-Tainan area, Taiwan. Tectonophysics, 554-557, 169-184, doi: 10.1016/j.tecto.2012.05.014. [Link]

Tsai, M. C., S. B. Yu, T. C. Shin, K. W. Kuo, P. L. Leu, C. H. Chang, and M. Y. Ho, 2015: Velocity field derived from Taiwan continuous GPS array (2007-2013). Terr. Atmos. Ocean. Sci., 26, 557-570, doi: 10.3319/ TAO.2015.05.21.01(T). [Link]

Tsan, S. F. and W. P. Keng, 1968: The Neogence rocks and major structure features of southwestern Taiwan. Petrol. Geol. Soc. China, 11, 45-49.

Tung, H. and J. C. Hu, 2012: Assessments of serious anthropogenic land subsidence in Yunlin County of central Taiwan from 1996 to 1999 by Persistent Scatterers InSAR. Tectonophysics, 578, 126-135, doi: 10.1016/j. tecto.2012.08.009. [Link]

Wakita, H., 1981: Precursory changes in groundwater prior to the 1978 Izu-Oshima-Kinkai earthquake. In: Simpson D. W. and P. G. Richards (Eds), Earthquake Prediction: An International Review, American Geophysical Union, Washington, D.C., 527-532, doi: 10.1029/ ME004p0527. [Link]

Ward, S. N., 1998: On the consistency of earthquake moment rates, geological fault data, and space geodetic strain: The United States. Geophys. J. Int., 134, 172186, doi: 10.1046/j.1365-246x.1998.00556.x. [Link]

Wdowinski, S., Y. Bock, J. Zhang, P. Fang, and J. Genrich, 1997: Southern California permanent GPS Geodetic Array: Spatial filtering of daily positions for estimating coseismic and postseismic displacements induced by the 1992 Lander earthquake. J. Geophys. Res., 102, 18057-18070, doi: 10.1029/97JB01378. [Link]

Wessel, P., W. H. F. Smith, R. Scharroo, J. Luis, and F. Wobbe, 2013: Generic Mapping Tools: Improved version released. EOS Trans. AGU, 94, 409-410, doi: 10.1002/2013EO450001. [Link]

Williams, S., 2003: The effect of coloured noise on the uncertainties of rates estimated from geodetic time series. J. Geod., 76, 483-494, doi: 10.1007/s00190-002-02834. [Link]

Wu, Y. M., C. H. Chang, L. Zhao, J. B. H. Shyu, Y. G. Chen, K. Sieh, and J. P. Avouac, 2007: Seismic tomography of Taiwan: Improved constraints from a dense network of strong-motion stations. J. Geophys. Res., 112, B08312, doi 10.1029/2007JB004983. [Link] 
Wu, Y. M., C. H. Chang, L. Zhao, T. L. Teng, and M. Nakamura, 2008a: A comprehensive relocation of earthquakes in Taiwan from 1991 to 2005. Bull. Seismol. Soc. Am., 98, 1471-1481, doi: 10.1785/0120070166. [Link]

Wu, Y. M., L. Zhao, C. H. Chang, and Y. J. Hsu, 2008b: Focal mechanism determination in Taiwan by genetic algorithm. Bull. Seismol. Soc. Am., 98, 651-661, doi: 10.1785/0120070115. [Link]

Wu, Y. Y., J. C. Hu, G. P. Lin, C. P. Chang, H. Tung, and C. H. Lu, 2013: Transient active deformation in Tainan Tableland using Persistent Scatterers SAR interferometry. Bull. Soc. Geol. France, 184, 441-450, doi: 10.2113/gssgfbull.184.4-5.441. [Link]

$\mathrm{Yu}$, S. B. and H. Y. Chen, 1994: Global positioning system measurements of crustal deformation in the Taiwan arc-continent collision zone. Terr. Atmos. Ocean. Sci., 5, 477-498, doi: 10.3319/TAO.1994.5.4.477(T). [Link]
Yu, S. B., H. Y. Chen, and L. C. Kuo, 1997. Velocity field of GPS stations in the Taiwan area. Tectonophysics, 274, 41-59, doi: 10.1016/S0040-1951(96)00297-1. [Link]

Yu, S. B., L. C. Kuo, R. S. Punongbayan, and E. G. Ramos, 1999: GPS observation of crustal deformation in the Taiwan-Luzon Region. Geophys. Res. Lett., 26, $923-$ 926, doi: 10.1029/1999g1900148. [Link]

Yu, S. B., Y. J. Hsu, L. C. Kuo, H. Y. Chen, and C. C. Liu, 2003: GPS measurement of postseismic deformation following the 1999 Chi-Chi, Taiwan, earthquake. J. Geophys. Res., 108, 2520-2539, doi: 10.1029/2003JB002396. [Link]

Zhang, J., Y. Bock, H. Johnson, P. Fang, S. Williams, J. Genrich, S. Wdowinski, and J. Behr, 1997: Southern California permanent GPS geodetic array: Error analysis of daily position estimates and site velocities. J. Geophys. Res., 102, 18,035-18,055, doi: 10.1029/97JB01380. [Link] 